Date of Publication: 30/07/2012

\section{Cunninghamia}

A journal of plant ecology for eastern Australia
The Royal

BOTANIC GARDENS ¿ Domain Trust

ISSN 0727-9620 (print) • ISSN 2200-405X (Online)

\title{
Understanding the characteristics of a groundwater-dependent ecosystem: Eucalyptus parramattensis Woodland at Porters Creek Wetland, NSW
}

\author{
Robert Payne ${ }^{1}$, Anita Chalmers ${ }^{2} \&$ John Laxton ${ }^{3}$ \\ ${ }^{1}$ Ecological Surveys \& Management, email: ecolsurvey@ netspace.net.au; \\ ${ }^{2}$ School of Environmental and Life Sciences, The University of Newcastle, PO Box 127, Ourimbah, NSW 2258 AUSTRALIA, \\ email: Anita.Chalmers@ newcastle.edu.au; ${ }^{3}$ John Laxton, email: john@laxton.nf
}

\begin{abstract}
Little is known about groundwater-dependent ecosystems in south-eastern Australia and few studies have examined the impact of landclearing upslope of such ecosystems. The eastern edge of Porters Creek wetland, near Warnervale on the Central Coast of New South Wales, supports a Eucalyptus parramattensis subsp. parramattensis (Parramatta Red Gum) population. The population has been listed as an Endangered Population (EP) and was showing signs of dieback during the 2002 to mid-2007 drought. Water table depth, soil moisture tension, soil temperature and groundwater salinity beneath this woodland were measured to investigate whether the woodland is associated with a shallow aquifer and/or high soil moisture conditions, and whether an upslope construction development would impact on the ecosystem. The composition, structure and health of the Eucalyptus parramattensis Woodland was also examined.
\end{abstract}

Monitoring over 5 years demonstrated that Eucalyptus parramattensis is associated with a shallow, slightly saline to saline (8-12 ppt) water table, 1.4-3.1 m beneath the surface of a drainage depression wetland. During the drought water table drawdown rates were quite rapid, and rainfall events took up to a month to replenish water table levels. Landclearing for an upslope development significantly decreased the average water table level by $0.3-0.5 \mathrm{~m}$ during the construction phase, while peaks that occurred at the base of the slope after large rainfall events reversed the normal direction of the water table gradient. The water table re-stabilised to pre-construction levels after construction was completed and the area was landscaped and revegetated with grass. The short-term alteration of groundwater conditions did not appear to impact on tree health; the poor tree health observed prior to construction was most likely due to the lowering of the water table (and/or an increase in groundwater/soil salinity) during the drought years.

Our results suggest that developments that revegetate slopes above wetlands as quickly as possible after clearing, or undertake clearing in stages, will minimise effects on water table levels. Pervious detention basins designed to capture runoff and allow infiltration into the soil help replenish aquifers, but also require weed maintenance. This study highlights the significance of maintaining shallow aquifer and catchment processes for the conservation and rehabilitation of coastal wetlands, many of which are listed as Endangered Populations or Endangered Ecological Communities.

Cunninghamia (2012) 12(3): 191-211

doi: 10.7751/cunninghamia.2012.12.016 


\section{Introduction}

Our understanding of groundwater-dependent vegetation in south-eastern Australia, and the potential impacts of urbanization on these ecological communities is generally lacking. Studies examining impacts on groundwaterdependent ecosystems are complicated by rainfall cycles (i.e. dry and wet periods). In Western Australia Groom et al. (2000b) reported that on the Swan Coastal Plain $80 \%$ of trees associated with an aquifer died as a result of rapid water table drawdown, and although the groundwater drawdown was attributed to human causes, below average rainfall resulting in limited water table recharge was a contributing factor. In contrast, in an area of the aquifer where rapid water table drawdown did not occur, no significant decrease in the abundance of overstorey or understorey plant species was detected. A similar study on the effects of long-term groundwater pumping in the United States found that lowering of the water table beneath a deep-rooted plant community reliant on groundwater (phreatophyte), resulted in continuing vegetation change 20 years after the drawdown began (Cooper et al. 2006). Vegetation changes resulting from hydrologic change are difficult to predict because under conditions of a lowered water table, while some species may show significant canopy dieback or death, drought tolerant species may survive with a reduced leaf area for decades, while some species may be able to grow roots to access deeper water tables. Where hydrologic changes are substantial, the whole community may change from one dominated by phreatophytes to one dominated by species with no dependency on the water table (Cooper et al. 2006).

Sand extraction from river beds can impact groundwaterdependent species by lowering the water table. For example in Colorado, Scott et al. (1999) found that sand excavation from the active channel of an ephemeral stream lowered the channel bed by up to $2 \mathrm{~m}$ and resulted in sustained declines in crown volume, stem growth and mortality of mature Populus deltoides subsp. monilifera trees, as well as increased leaf desiccation and branch dieback. Whilst water and sand extraction may lower the water table, catchment urbanization can either increase or decrease water tables, depending on the nature of the development. The proportion of catchment imperviousness and forested area, and the degree of outlet constriction were the most important factors affecting wetland hydroperiod in a study on the impact of urban stormwater on 19 wetlands in Washington State USA (Reinelt et al. 1998).

Some groundwater-dependant vegetation communities tolerate saline conditions. Morris and Collopy (1999) investigated water use and salt accumulation by Eucalyptus camaldulensis River Red Gum and Casuarina cunninghamiana River Oak on a site with shallow (0.7-3.0 $\mathrm{m}$ deep) saline groundwater in northern Victoria. Modelled results indicated that more than half of the water uptake was sourced from groundwater. They also found that soils were slight to moderately saline below $30 \mathrm{~cm}$ depth, reaching a maximum salinity at around $200 \mathrm{~cm}$. Soil salinity varied seasonally in response to water table movements. One of the reasons for the decline of riparian vegetation in semi-arid regions of Australia is increased salt accumulation in the soil. In healthy Eucalyptus largiflorens Black Box woodlands on the lower River Murray, the trees opportunistically use low-salinity deep soil water, that overlies highly saline groundwater (Holland et al. 2006). In this ecosystem, recharge of the water table occurs by vertical seepage through the soil profile, and horizontal bank recharge from surface water within $50 \mathrm{~m}$ of a permanent or ephemeral stream. In a closed canopy swamp forest in South Australia, Mensforth and Walker (1996) showed that Melaleuca halmaturorum uses saline groundwater (41 ppt; 0.3-1.2 m deep) in summer and a combination of rainfall and groundwater in winter. An ability to rapidly re-activate dormant roots in response to changes in soil water availability contributes to its survival. Mensforth and Walker (1996) also noted that dilution of stored salt in the unsaturated zone with winter rainfall and the subsequent groundwater rise is a process important to the survival of Melaleuca halmaturorum trees.

The rehabilitation of Endangered Ecological Communities (EECs) and Endangered Populations (EPs) is a growing industry but there is little research to support the development of rehabilitation targets and strategies (Hill et al. 2005; Kooyman \& Rossetto 2006; Mackenzie \& Keith 2009). A small population of Eucalyptus parramattensis subsp. parramattensis (Parramatta Red Gum) trees on a small area (about 3.7 hectares) near Warnervale, on the Central Coast of New South Wales, has been listed as an Endangered Population (EP) under the NSW Threatened Species Act. The Eucalyptus parramattensis Woodland grows on a drainage depression adjacent to Porters Creek Wetland, but at the upstream end of the catchment. The habitat of Eucalyptus parramattensis is generally considered to be low-lying and often wet sites (Benson \& McDougall 1998; Harden 1991). Observations along the Georges River in Sydney and at the current study site in Warnervale by the first author (RP) suggested an association between Eucalyptus parramattensis and a shallow water table; evidenced by associated vegetation and water often over the ground surface. From 2002 to mid-2007, the Central Coast of New South Wales (NSW) experienced a significant drought. Observations at Warnervale revealed that a small number of Eucalyptus parramattensis trees were under stress, or had died; this was the only species suffering from this condition.

Although part of the Warnervale Eucalyptus parramattensis Endangered Population is now in a 1.3 ha reserve managed under a NSW Office of Environment and Heritage (OEH) voluntary conservation agreement, our ability to restore the remainder of the EP back to its original condition may be limited. Prior to its gazettal a proposal for a school on two adjacent land parcels to the north and south of the EP was approved. An arterial road was also subsequently approved. Concerns were raised that if the Eucalyptus parramattensis Woodland is dependent on shallow groundwater, construction 
may alter the groundwater characteristics of the site and negatively affect the EP.

This study examines: (i) the structure and health of the Eucalyptus parramattensis population, (ii) whether the population is associated with a shallow aquifer and/or high soil moisture conditions and (iii) whether groundwater or soil moisture conditions were significantly altered during the construction and post-construction stages of an upslope development. This information will allow more informed decisions to be made with respect to managing and rehabilitating groundwater-dependent Endangered Ecological Communities and Endangered Populations.

\section{Methods}

\section{Study area}

Porters Creek Wetland is the largest single-bodied freshwater wetland between Sydney and Newcastle, and a major part of its catchment is subject to continuing development. The Eucalyptus parramattensis Woodland study area is located in a drainage depression on the eastern edge of the Porters Creek Wetland at Warnervale north of Wyong (Dooralong 1:25 000 mapsheet AMG co-ordinates $56^{3} 54$ 9993E, ${ }^{63} 20$
$477 \mathrm{~N}$ ) between the junior and senior schools of the Lakes Grammar School (Figure 1). The drainage depression is underlain by Patonga Claystone (red-brown siltstone and claystone probably deposited on a well-drained, meandering, alluvial floodplain - Uren 1975) and soils of alluvial origin.

The study site covers about 3.7 ha and has two distinctly different areas with different past management histories, a relatively undisturbed Western area, and a more disturbed Eastern area (Figure 2). The Western undisturbed area has well-separated trees of Eucalyptus parramattensis as emergents, with a dense midstorey canopy of Melaleuca nodosa and occasional Melaleuca sieberi giving the impression of a closed canopy (labelled PRG in Figure 1). The understorey is generally sparse or non existent for most of the year, and when ground vegetation does appear, it attracts grazing by the Red-necked Wallaby Macropus rufogriseus. Within this sparse ground layer a large orchid population can emerge during August, comprising Caladenia catenata, Caladenia carnea, Pterostylis nutans, Pterostylis longifolia and Thelymitra angustifolia. Within the more low lying wet area of the mature forest, are pockets of graminoids such as Gahnia clarkei, Carex appressa, Lepidosperma quadrangulatum and Lomandra longifolia.

The Eastern area appears to have been previously cleared and grazed; the presence of an old dam to the south (Figure

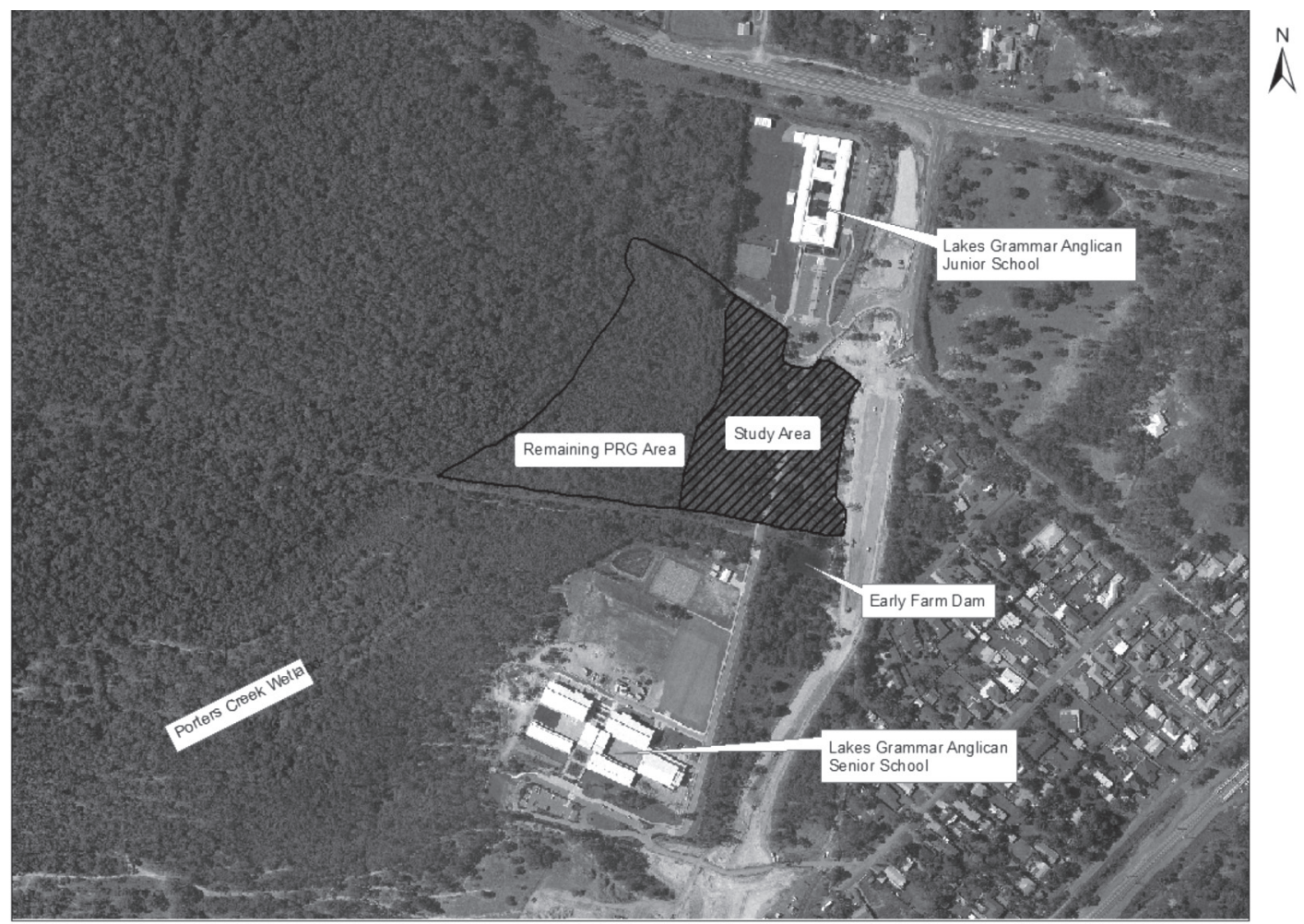

Fig. 1. Air photo showing Lakes Grammar-an Anglican School in 2011, with the Eucalyptus parramattensis Woodland Study Area (hached) between the junior and senior schools. A road divides the Study Area into Western and Eastern sampling areas. Porters Creek Wetland is located to the south-west. The arterial road is under construction to the east. Source: NearMap website. 
1) suggests it was farmed, but use of the area had stopped many years before this study started. In contrast to the mature Western woodland, this area supports pockets of immature trees of Eucalyptus parramattensis together with occasional trees of Eucalyptus robusta (Swamp Mahogany), Eucalyptus tereticornis (Forest Red Gum) and Angophora costata (Sydney Red Gum). Regenerating midstorey trees of the same species are also present. The groundcover is dense and includes native grasses such as Imperata cylindrica var. major Blady Grass, but is dominated by the exotic grasses, Andropogon virginicus, Pennisetum clandestinum and Axonopus affinis (Figure 2).

Downstream of the Eucalyptus parramattensis Woodland the vegetation merges into Eucalyptus tereticornis Forest with dense Gahnia clarkei sedgeland understorey. Further downstream, the vegetation comprises a mosaic of vegetation types such as Low Forest dominated by Eucalyptus robusta, Low Forest/Forest dominated by Melaleuca quinquenervia and Casuarina glauca, Low Swamp Forest dominated by Angophora costata, Angophora floribunda, Eucalyptus tereticornis, Eucalyptus longifolia and Eucalyptus robusta and Closed Heath Ti-tree Scrub dominated by Melaleuca ericifolia (see vegetation mapping by Payne \& Duncan 1999; Bell 2002).

The drainage depression supported a population of just in excess of 100 Eucalyptus parramattensis trees between 2003 and 2008 within the study area and extending about $80 \mathrm{~m}$ to the west of the study area onto private property. However, there is now very little Eucalyptus parramattensis left outside these areas as the new road was constructed during 2009 and 2010 (see Figure 1).

Patonga Claystone geology also outcrops south of the study area, on a slope that once supported a mixed Spotted Gum - Ironbark Forest dominated by Corymbia maculata,

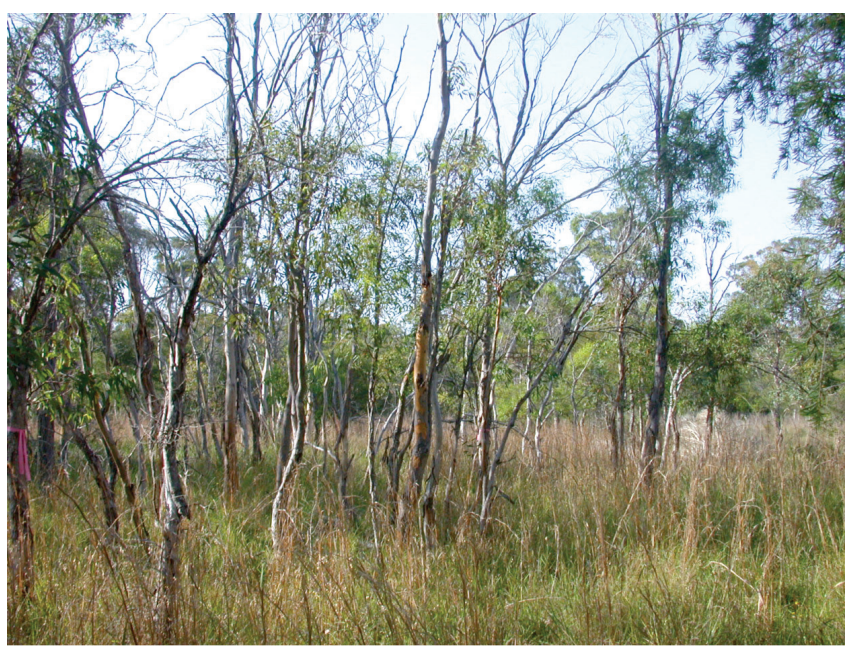

Fig. 2. Regrowth Eucalyptus parramattensis Woodland in the disturbed Eastern area, showing dense exotic grass cover of Andropogon virginicus and tree dieback in July 2003.
Eucalyptus fibrosa and Eucalyptus siderophloia, Eucalyptus globoidea, Corymbia gummifera and Angophora costata, with a mid dense sub-canopy of Melaleuca nodosa and Melaleuca sieberi (Figure 4). This spotted gum forest was harvested from time to time for mine pit props but has now all been cleared for the senior school (Figure 4).

\section{Tree condition}

Tree condition was assessed in September 2003 (during the drought) and again at the end of the project in July 2011. Nine trees in the Western area and ten trees in the Eastern areas were randomly selected and condition assessed using the method of Groom et al. (2000b), where $1=1-25 \%$ foliage loss; $2=26-50 \%$ foliage loss; and $3=51-100$ foliage loss. The same trees were not necessarily assessed at the two sampling times because many of the original labels had disappeared and a number of the selected trees had been removed as a result of construction of the new internal and arterial road. Therefore, trees that were still labeled were re-measured and others were selected from the few that remained.

\section{Vegetation sampling}

As the study area is only small (about 3 ha) and the vegetation uniform, one $50 \mathrm{~m} \times 50 \mathrm{~m}$ plot was set out in

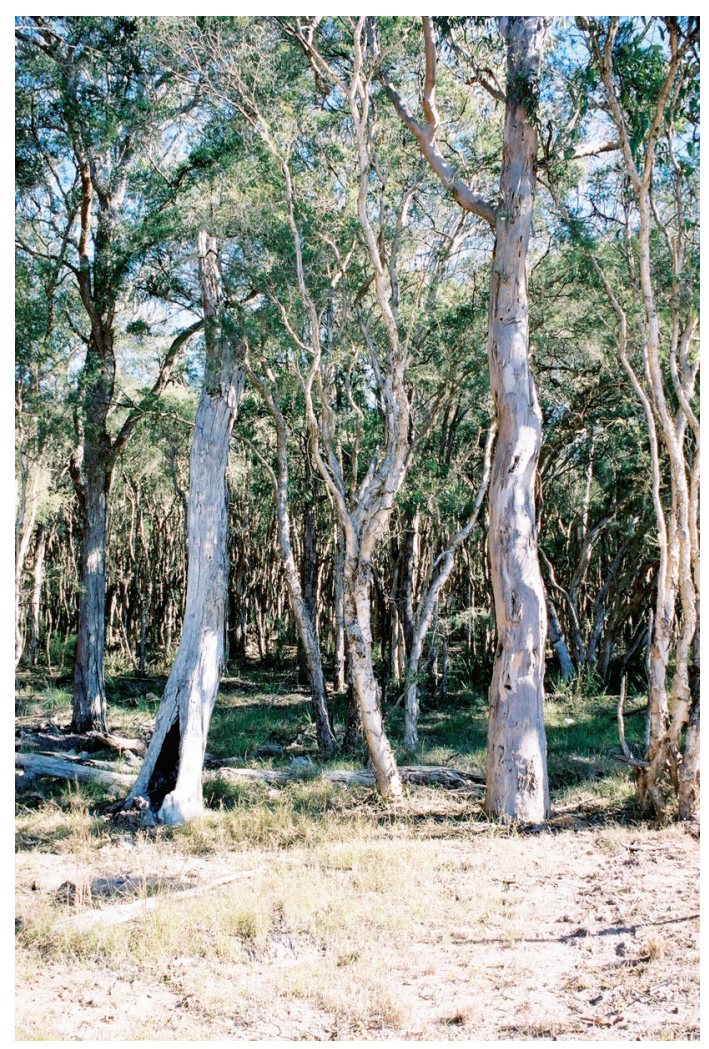

Fig. 3. Mature Eucalyptus parramattensis Woodland in the undisturbed Western area, showing the Melaleuca sieberi and Melaleuca nodosa sub-canopy and the sparse ground vegetation cover in July 2003. 


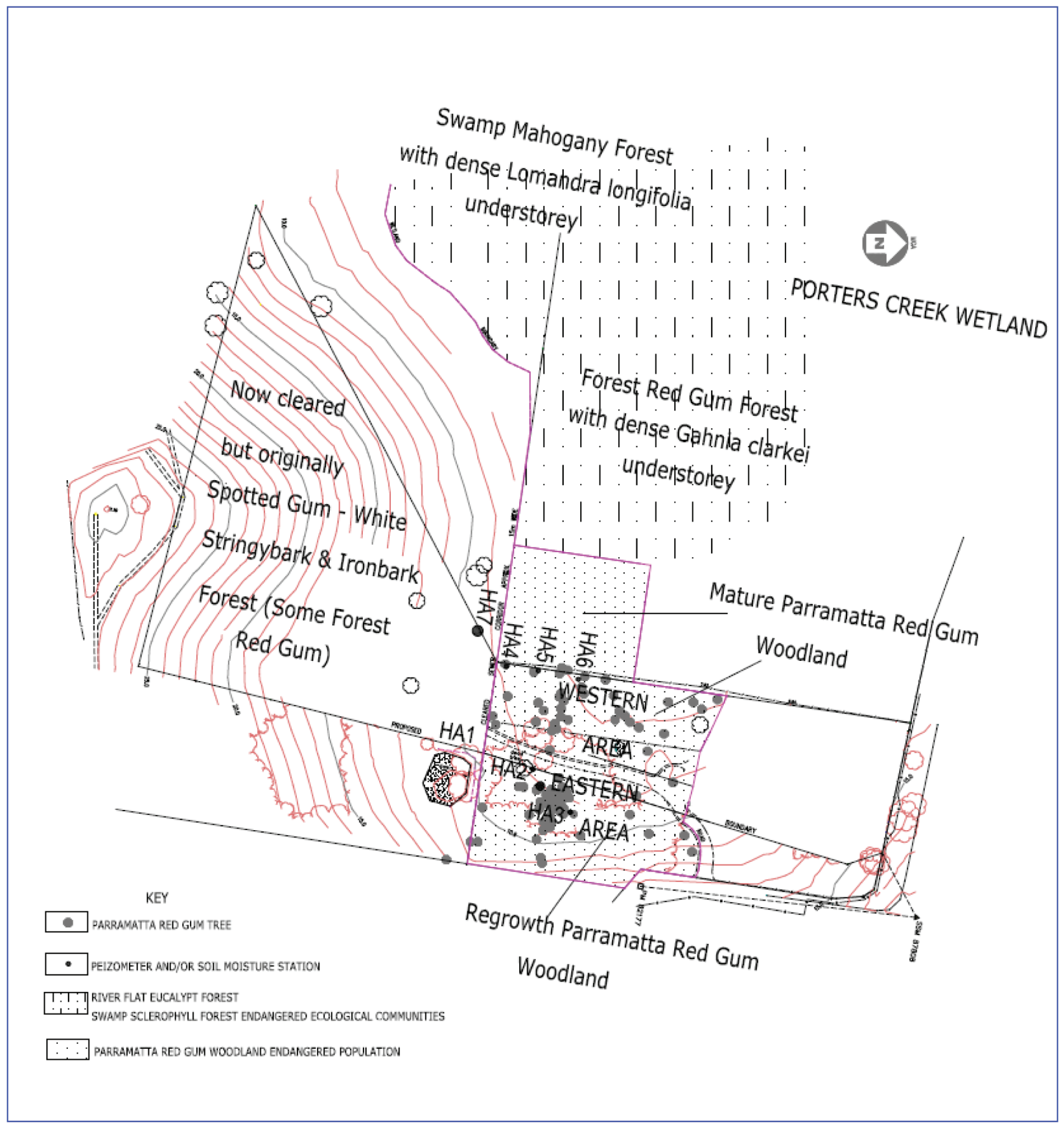

Fig. 4. The study area at Warnervale showing the location of Eucalyptus parramattensis trees in grey. Piezometer locations (HA1-HA3) are shown along a $200 \mathrm{~m}$ gradient. To the south the Spotted Gum- White Stringybark- Ironbark Forest on a Patonga Claystone slope has now been cleared. (Original base plan prepared by Trehy, Ingold \& Neate Surveyors, 2002 and amended 2012.) 
each of the eastern and western areas and all trees with a diameter at breast height $(\mathrm{dbh})>10 \mathrm{~cm}$ were measured and the species recorded. For the overall canopy tree composition, basal area was measured and stand importance values (SIV) were calculated by averaging the relative density and relative dominance data for each tree species. Tree size class histograms were prepared. Further vegetation sampling using three randomly selected $20 \mathrm{~m} \times 20 \mathrm{~m}$ plots was undertaken using the standard procedure of HCCREMS, which at that time used a 1-6 Braun Blanquet scale for cover abundance scores for each species recorded in the quadrat. This information provided a plant species list for this vegetation community.

\section{Soil and groundwater investigation}

Piezometers were located at the upstream edge of the drainage depression and across the tributary to establish whether changes in water table depth and gradient occurred between the pre-, during-construction and post-construction stages of development. Pre-construction (Stage 1) monitoring began in December 2004 and finished in March 2006. During this time the Junior School was built but this was downslope of the Eucalyptus parramattensis and had no impact on the water table. Water table measurements were undertaken during this time to obtain the normal undisturbed water table profile. Stage 2, the construction stage (April 2006 to January 2007) involved clearing the Spotted Gum Forest on the southern slope and construction of the Senior School, which is upslope of the Eucalyptus parramattensis Woodland. During Stage 2 a second pervious artificial wetland was constructed at the base of the north-eastern facing slope. During the post-development stage, measurements were sporadic as the project was deemed finished. However when some smaller drainage works and an oval were subsequently constructed, water tables were again measured (March 2009-March 2010).

In 2003, before construction commenced, three water table monitoring stations (HA1-HA3) were installed across the drainage depression in the Eastern area (Table 1; Figure 4). In August 2009 HA5 was installed to measure changes in the groundwater depth at a downstream location in the Western area (Table 1; Figure 4). Soil profile characteristics beneath the Eucalyptus parramattensis Woodland, as well as depths to the water table and bedrock were recorded during piezometer installation.

Water table depths were measured in the piezometers fortnightly or monthly (February 2003-February 2008 and from April 2009-March 2010). HA5 was monitored from September 2009-March 2010. Groundwater depths were converted to Australian Height Datum (AHD) reduced levels because the top of each piezometer was levelled into a state survey mark (Table 1). Water was extracted at each piezometer by a submersible 12 volt pump. A calibrated YeoKal Model 611 Intelligent Water Quality Analyser was used to measure groundwater salinity. Soil moisture tension was measured at the same locations as the piezometers (HA1HA3) and at an additional three stations (HA4-HA6) located in the western area. At each station gypsum blocks were inserted into the soil at a depth of $300 \mathrm{~mm}$ below the surface. Soil temperature (at the ground surface) and soil moisture tension were measured each fortnight between June 2003 and March 2006.

\section{Statistical analyses}

Water table level and soil temperature data were normally distributed. Soil moisture data were not normally distributed and were log transformed, where required. A two-tailed t-test was conducted to determine if there was a significant difference in the mean soil temperature within the regrowth (eastern) and the mature (western) Eucalyptus parramattensis Woodland. Spearman correlations were used to determine the relationship between monthly rainfall, soil moisture tension, soil temperature and water table level. As the water table levels in the three piezometers were measured a number of times the effect of the piezometer location (i.e. HA1, HA2, HA3) and the treatment (i.e. pre-, during and after construction) was assessed using repeated measures ANOVA, which was also used to test for differences in groundwater salinity. For these analyses, Levene's test of equality of error variances and Box's test of equality of covariance indicated that the assumptions of homogeneity of error variance and homogeneity of covariance (i.e. compound symmetry) had not been violated (Tabachnick and Fidell 1989). Tests of significance for the repeated measures ANOVA used the more conservative Greenhouse-Geiser and Huynh-Feldt statistics (Tabachnick and Fidell 1989). As monthly rainfall

Table 1. Location and height data for piezometer (P) and/or soil moisture (SM) stations. AHD = Australian Height Datum.

$\begin{array}{llllll}\text { Station } & \text { Easting } & \text { Northing } & \text { Height }(\mathbf{m}) \text { AHD } & \text { Installation Date } & \text { Notes } \\ \text { HA1 } & { }^{3} 54973.12 & { }^{63} 20404.02 & 10.16 & 20.1 .2003 & \text { P;SM } \\ \text { HA2 } & { }^{3} 55020.07 & { }^{63} 20466.88 & 9.31 & 20.1 .2003 & \text { P;SM } \\ \text { HA3 } & { }^{3} 55060.68 & { }^{63} 20502.13 & 9.41 & 20.1 .2003 & \text { P;SM } \\ \text { HA4 } & { }^{3} 54922.78 & 6320441.95 & & 20.1 .2003 & \text { SM } \\ \text { HA5 } & { }^{3} 54927.18 & 6320471.20 & 8.76 & 20.1 .2003(\text { SM) } 12.8 .2009 \text { (P) } & \text { P;SM } \\ \text { HA6 } & { }^{3} 54934.68 & 6320509.76 & & 20.1 .2003 & \text { SM }\end{array}$


data was not normally distributed, differences among pre-, during and post-construction rainfall were examined using the non-parametric Kruskal Wallis test. The difference in mean tree condition at the start and end of the study was tested using ANOVA, after substituting the midpoint of each foliage loss class for the condition scale (i.e. $1=12 \%$ loss; $2=38 \%$ loss; $3=75.5 \%$ loss). All analyses were conducted using SPSS version 17.

\section{Results -Prior to construction}

\section{Tree condition}

For the Eucalyptus parramattensis individuals sampled, there was a lower basal area and lower stem density in the Eastern area compared to the Western area, and size classes were smaller (25-190 mm dbh - Eastern, 70-250 mm dbh - Western) (Table 2; Figure 5), suggesting past removal of trees and some more recent recruitment. Dieback was

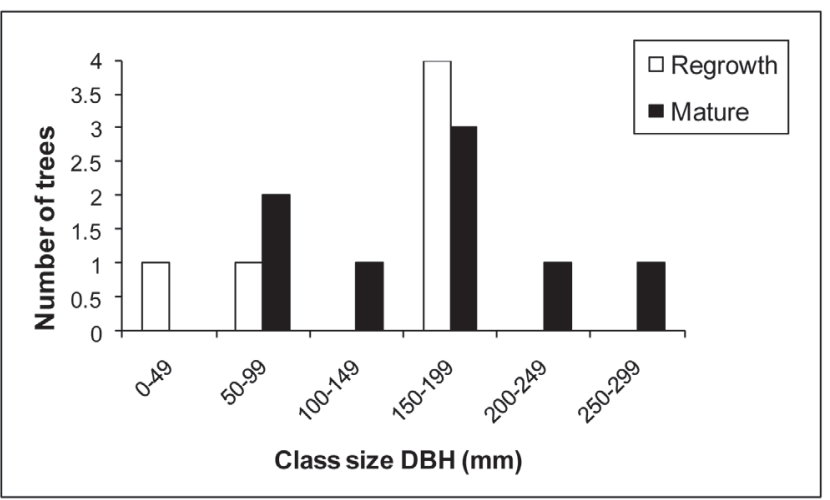

Fig. 5. Size class distribution of Eucalyptus parramattensis in each of the $50 \times 50 \mathrm{~m}$ quadrats in the regrowth (eastern) and mature (western) Eucalyptus parramattensis Woodland at the Warnervale study area. $\mathrm{DBH}=$ diameter at breast height. evident in all Eucalyptus parramattensis trees in both the eastern and western areas in early 2003, but tree death was particularly noticeable in the Eastern area (Figure 2). However, this latter observation was not quantified, as dead trees were not selected for the assessment of tree condition (i.e. foliage loss). This perhaps was due to the fact the trees at this location were regrowth.

\section{Vegetation and soils}

Despite having its highest basal area in the Western woodland, Eucalyptus parramattensis had a low stand importance value (SIV) in comparison with the Melaleuca understory stratum. Melaleuca nodosa had the highest SIV in the Western woodland while Melaleuca sieberi had the highest SIV in the Eastern woodland (Table 2). The full description of the composition of the Eucalyptus parramattensis Woodland is given in Appendix 1.

The sub-surface soil profile below the Eucalyptus parramattensis Woodland consisted of plastic clay to depths ranging from $3.35 \mathrm{~m}$ (at HA3) to the maximum depth of investigation of $4.45 \mathrm{~m}$ (at HA1), overlying a fine to coarse grained clayey sand (Figure 6). The contact between the clayey and sandy soils corresponded to a level at about $4 \mathrm{~m}$, just below RL $6 \mathrm{~m}$ AHD (the surface is between 9-10 $\mathrm{m}$ AHD).

\section{Groundwater}

During piezometer installation, groundwater inflows were encountered at $3.5 \mathrm{~m}$ depth below the ground surface in $\mathrm{HA} 1$, at $2.5 \mathrm{~m}$ in HA2 and at $3.1 \mathrm{~m}$ in HA3. Each standpipe was bailed dry after installation and the water table allowed to develop over a period of two days. Following this, static water table measurements of $3.12 \mathrm{~m}, 1.82 \mathrm{~m}$ and $1.57 \mathrm{~m}$ were recorded at HA1, HA2 and HA3, respectively (giving water table levels of 6.9, 7.18 and $7.63 \mathrm{~m} \mathrm{AHD)} \mathrm{and} \mathrm{after} \mathrm{a} \mathrm{three}$ year period mean water RLs of $6.52 \mathrm{~m}, 7.09 \mathrm{~m}$ and $7.45 \mathrm{~m}$ were recorded. The initial groundwater table was found to lie within a lens of sandy clay, confined between the silty

Table 2. Abundance of woody species recorded within two $50 \mathrm{~m}$ x $50 \mathrm{~m}$ quadrats within the Eastern (regrowth) and Western (mature) Eucalyptus parramattensis woodland at the Warnervale study area. BA = basal area; SIV = stand importance value. Dead stems were not recorded in the SIV survey. Recorded January 2004 for the mature woodland and February 2004 for the regrowth woodland.

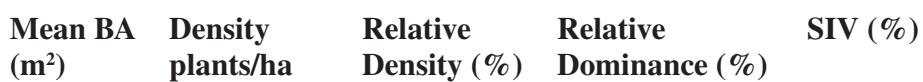

\begin{tabular}{|c|c|c|c|c|c|c|c|}
\hline \multirow{4}{*}{$\begin{array}{l}\text { Eastern } \\
\text { (regrowth) }\end{array}$} & Angophora floribunda & canopy & 0.27 & 2 & 0.5 & 1 & 1 \\
\hline & Eucalyptus parramattensis & canopy & 0.21 & 12 & 3 & 5 & 4 \\
\hline & Melaleuca nodosa & shrub & 0.19 & 76 & 17 & 22 & 19 \\
\hline & Melaleuca sieberi & shrub & 0.11 & 354 & 80 & 72 & 76 \\
\hline \multirow{3}{*}{$\begin{array}{l}\text { Western } \\
\text { (mature) }\end{array}$} & Eucalyptus parramattensis & canopy & 0.25 & 32 & 4 & 6 & 5 \\
\hline & Melaleuca nodosa & shrub & 0.17 & 536 & 59 & 65 & 62 \\
\hline & Melaleuca sieberi & shrub & 0.12 & 396 & 37 & 30 & 34 \\
\hline
\end{tabular}


clay soil and Patonga Claystone bedrock (Figure 6). This soil layer, in the vicinity of the Eucalyptus parramattensis trees, was in the order of 1.9-2.1 m below the ground surface.

Elevation and the depth of the water table below the ground surface varied across the $200 \mathrm{~m}$ transect (Figure 6). Elevation of HA1 was greater than HA2 and HA3, while the elevation of HA2 was slightly lower than HA3 (Table 1; Figure 6). The water table was deepest below HA1 and closest to the surface at HA3 (Figure 6). After three years of monitoring the water table gradient beneath the drainage depression was relatively consistent and dipped to the southwest (i.e. sloping from HA3 to HA1). Eucalyptus parramattensis trees were growing in greater numbers between piezometers HA2 and HA3, and the results support the view that Eucalyptus parramattensis occurs in locations where water table levels are higher (see Figure 4).

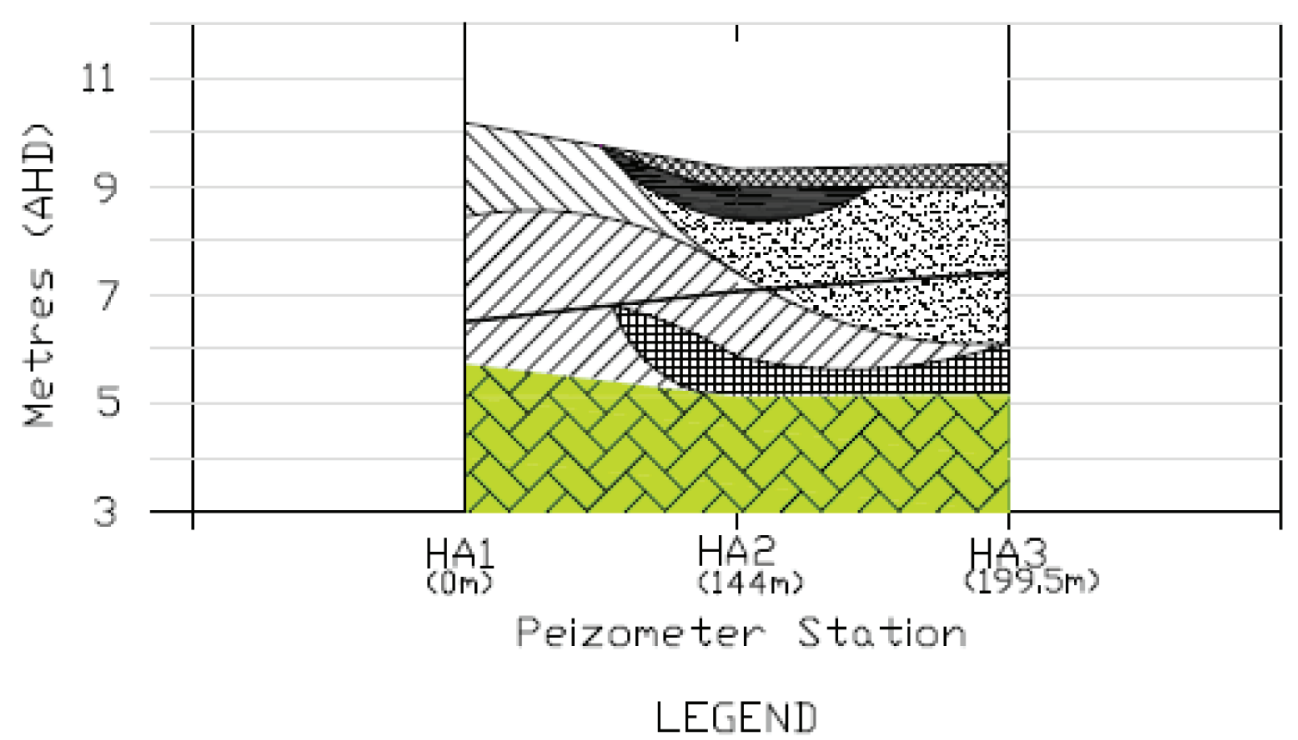

Surface layer of very loose dark brown silty sand with some organic matter $\mathrm{M}$ Pale grey to grey mottled orange brown clay

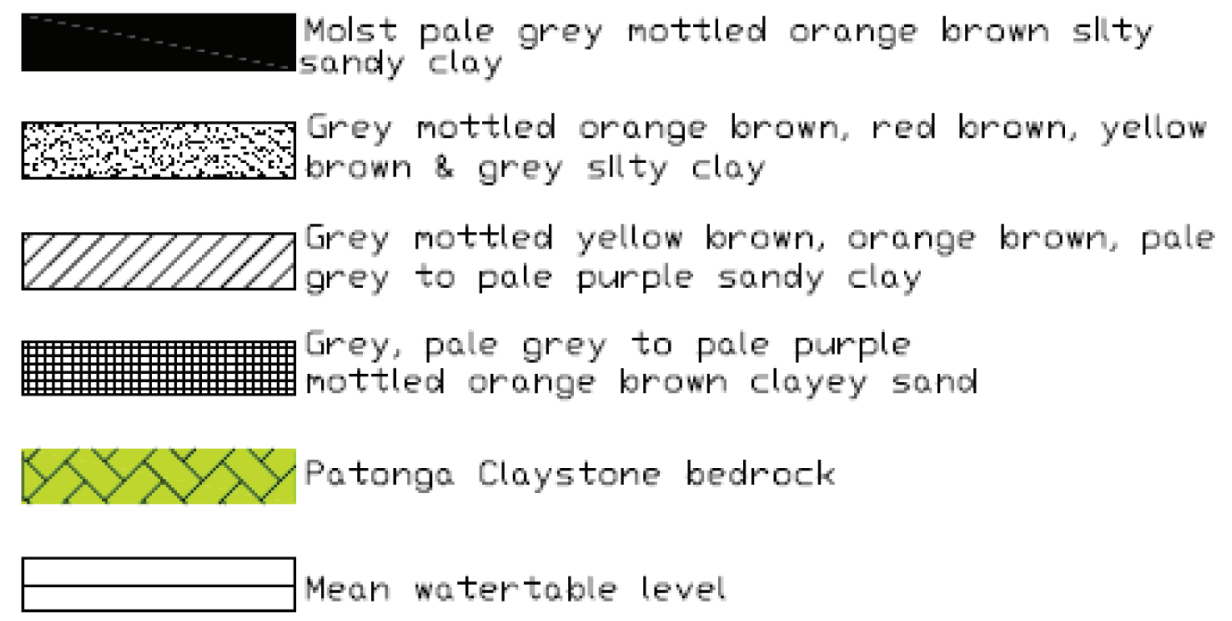

Fig. 6. Cross-section showing water table and soil profiles within the Eucalyptus parramattensis Woodland (eastern area). Information collated from the various borehole logs undertaken during the study by Coffey Geosciences. Locations of the piezometer stations (HA1 HA3) are shown on Figure 4. 
Over the three-year pre-construction period the mean water table level beneath the Eucalyptus parramattensis Woodland ranged between 5.7-8.2m AHD (Figure 7) (mean depth below the surface at HA2 was $2.24 \mathrm{~m}$ ). The water tables rose $0.8-1.0 \mathrm{~m}$ during the initial sixth month period up to July 2003 (Figure 7). Rainfall of $681 \mathrm{~mm}$ was received between March and July 2003 including a peak of $328 \mathrm{~mm}$ in May (records from Wyong Golf Club, $2.8 \mathrm{~km}$ south). This rainfall caused a substantial rise in the water table, although there was a time lag (Figure 7). From this time onwards the groundwater gradually dropped to very low levels until no water was recorded in the piezometers. Low water tables were still being recorded in October 2004 (despite $271 \mathrm{~mm}$ of rain for that month). These observations indicate that the peak of the drought was between May and September 2004, and that when rainfall events did occur, the rainwater (taking into account losses from evaporation and transpiration) took at least one month to infiltrate through the soil and recharge the aquifer. From October 2004 the water table slowly began to rise towards previous levels peaking in July 2005. After the water tables were drawn down again in February 2006, no water was recorded in the piezometers. Average drawdown rates, during the drier period of the study (February 2003September 2004), were $0.8 \pm 0.1 \mathrm{~m}$ over 3 months (Figure 7).
$\mathbf{A}$

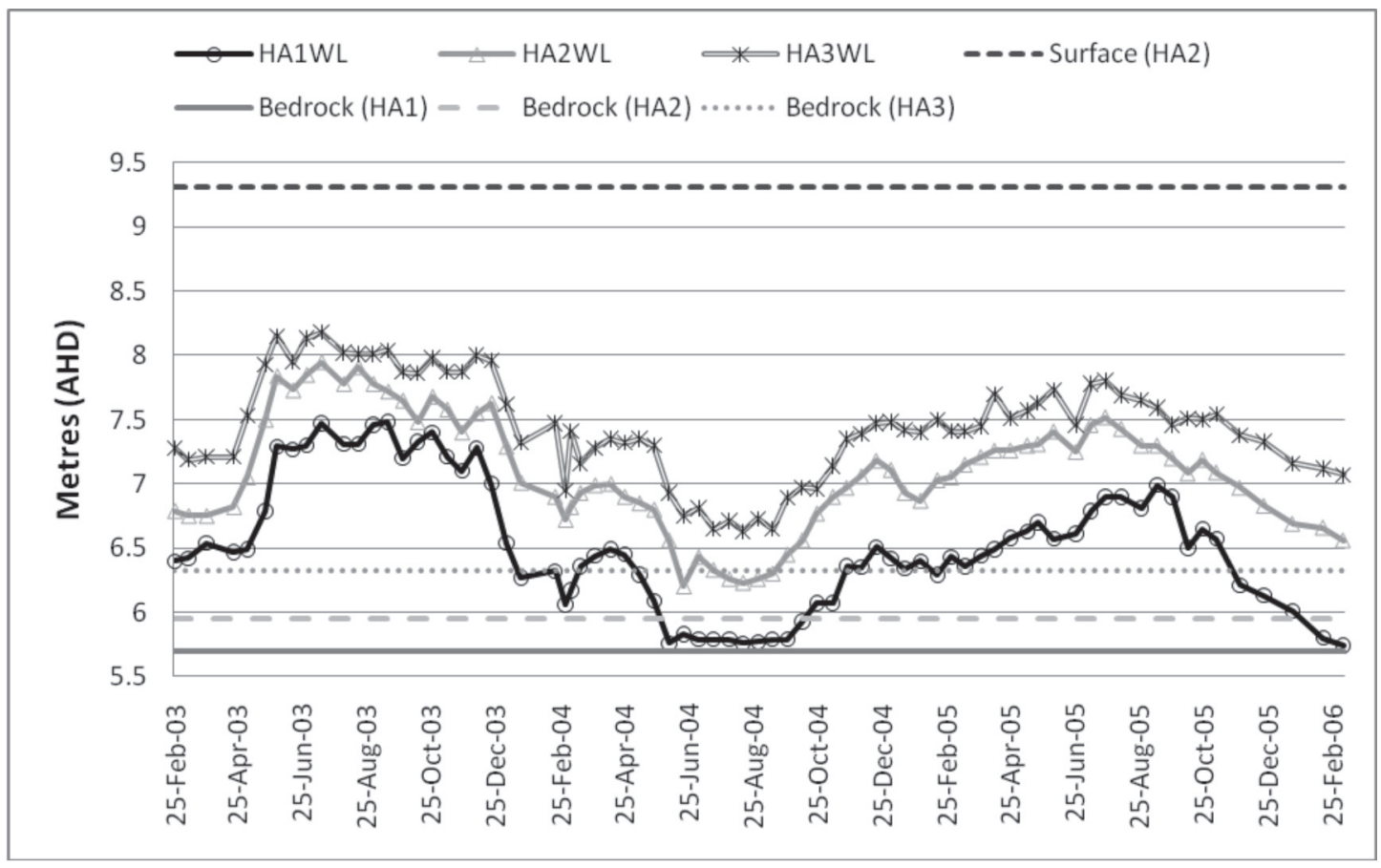

B

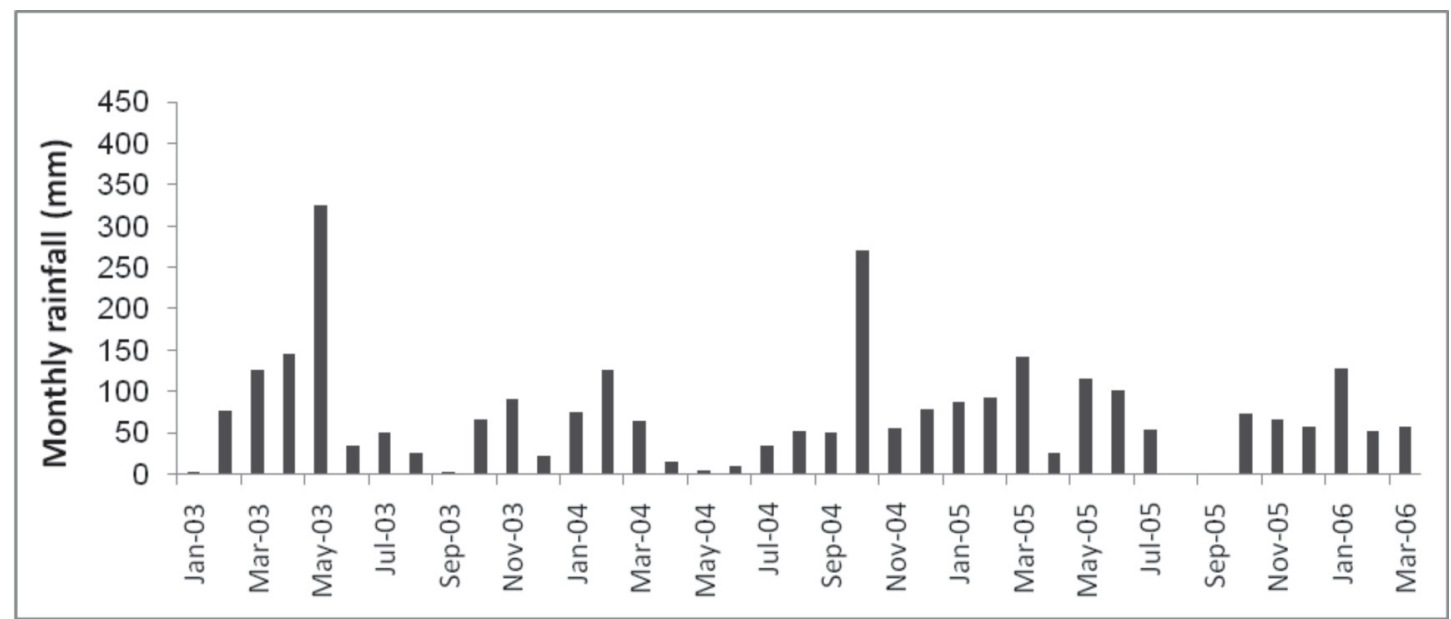

Fig. 7. Measured variable prior to construction (a) water table level and bedrock elevations for each piezometer (HA1, HA2 \& HA3) and ground surface at HA2; (b) monthly rainfall (Wyong Golf Club). See Figure 4 for the location of the three piezometers within the study area. 
A

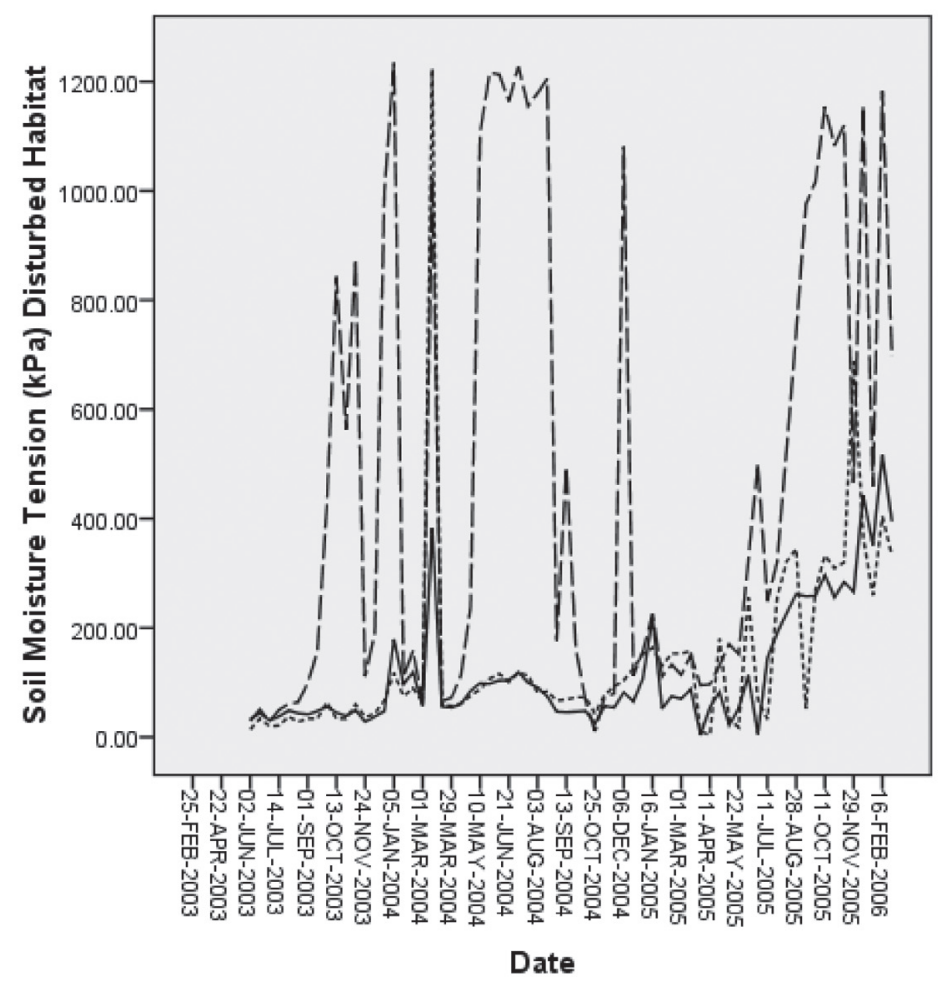

$$
\begin{gathered}
\text { - ha1 } \\
\text {-na2 } \\
\text {-.-n ha3 }
\end{gathered}
$$

\section{Date}

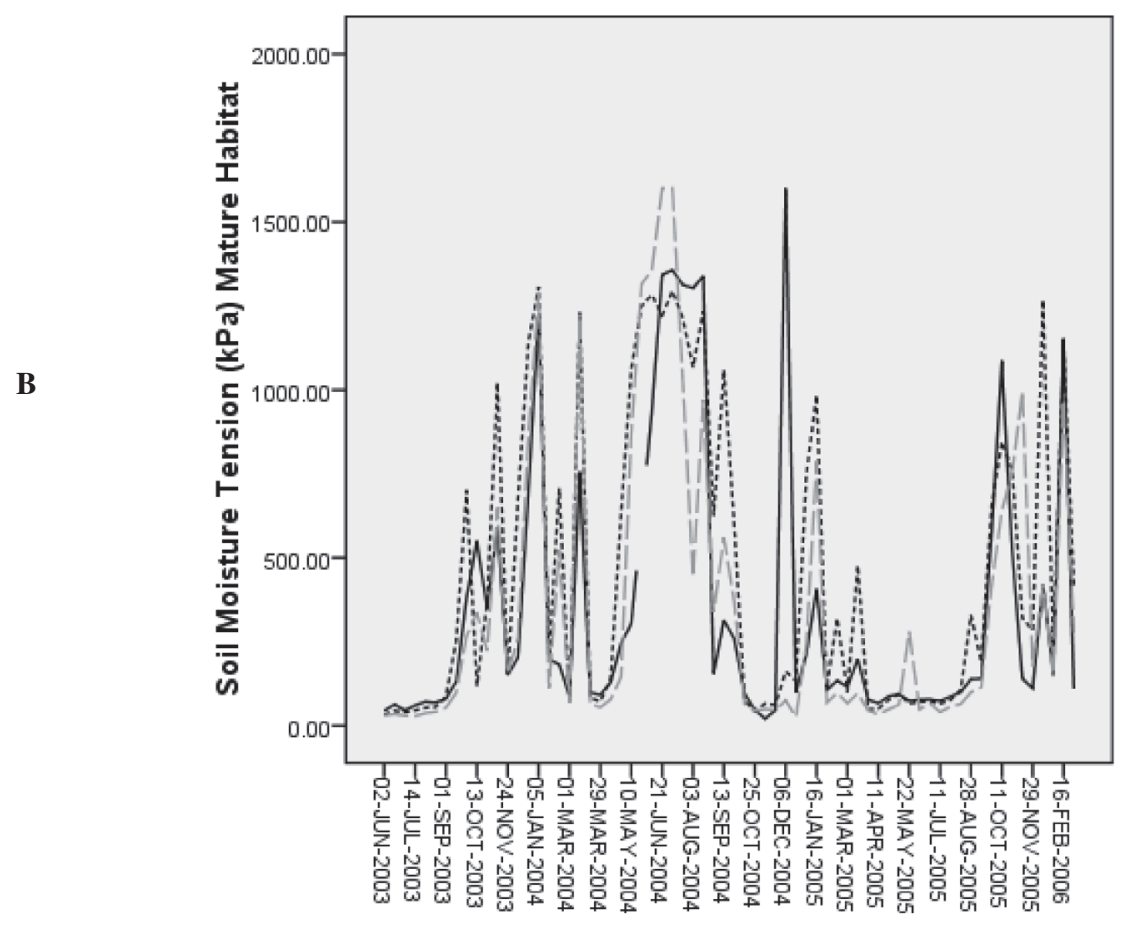

- ha4sMPRECON

--- ha5smPRECON

- =ha6smPRECON

Date

Fig. 8. Soil moisture tension in (a) eastern-regrowth and (b) western-mature Eucalyptus parramattensis Woodland prior to construction (n $=67)$. The higher the soil moisture tension value the wetter the soil. 
Table 4. Soil moisture tension $(n=67)$ and soil temperature $(n=68)$ conditions in the mature (western) and regrowth (eastern) Eucalyptus parramattensis Woodland prior to construction. See Figure 4 for the location of the soil moisture stations (HA1 - HA6). The higher the soil moisture tension, the wetter the soil.

\begin{tabular}{llllllll} 
& & \multicolumn{3}{c}{ Eastern -Regrowth Forest } & \multicolumn{3}{c}{ Western-Mature Forest } \\
& & HA1 & HA2 & HA3 & HA4 & HA5 & HA6 \\
& & & & & & & \\
Soil & Mean $( \pm$ SE) & $472 \pm 54.3$ & $119 \pm 13.9$ & $143 \pm 22.3$ & $352 \pm 51.7$ & $453 \pm 54.5$ & $347 \pm 51.3$ \\
Moisture & Median & 226 & 70 & 78 & 140 & 235 & 114 \\
$(\mathrm{kPa})$ & Minimum & 11 & 4 & 4 & 21 & 33 & 26 \\
& Maximum & 1234 & 516 & 1223 & 1600 & 1308 & 1600 \\
Soil & Amplitude & 1223 & 512 & 1219 & 1579 & 1275 & 1574 \\
Temperature & Mean $( \pm$ SE) & $21 \pm 0.6$ & $21 \pm 0.7$ & $21 \pm 0.7$ & $19 \pm 0.6$ & $19 \pm 0.6$ & $19 \pm 0.7$ \\
$\left({ }^{\circ} \mathrm{C}\right)$ & Median & 21 & 21 & 21 & 19 & 19 & 19 \\
& Minimum & 4 & 3 & 6 & 4 & 3 & 3 \\
& Maximum & 33 & 34 & 34 & 31 & 33 & 34 \\
& Amplitude & 28 & 32 & 28 & 27 & 30 & 31
\end{tabular}

$\mathbf{A}$
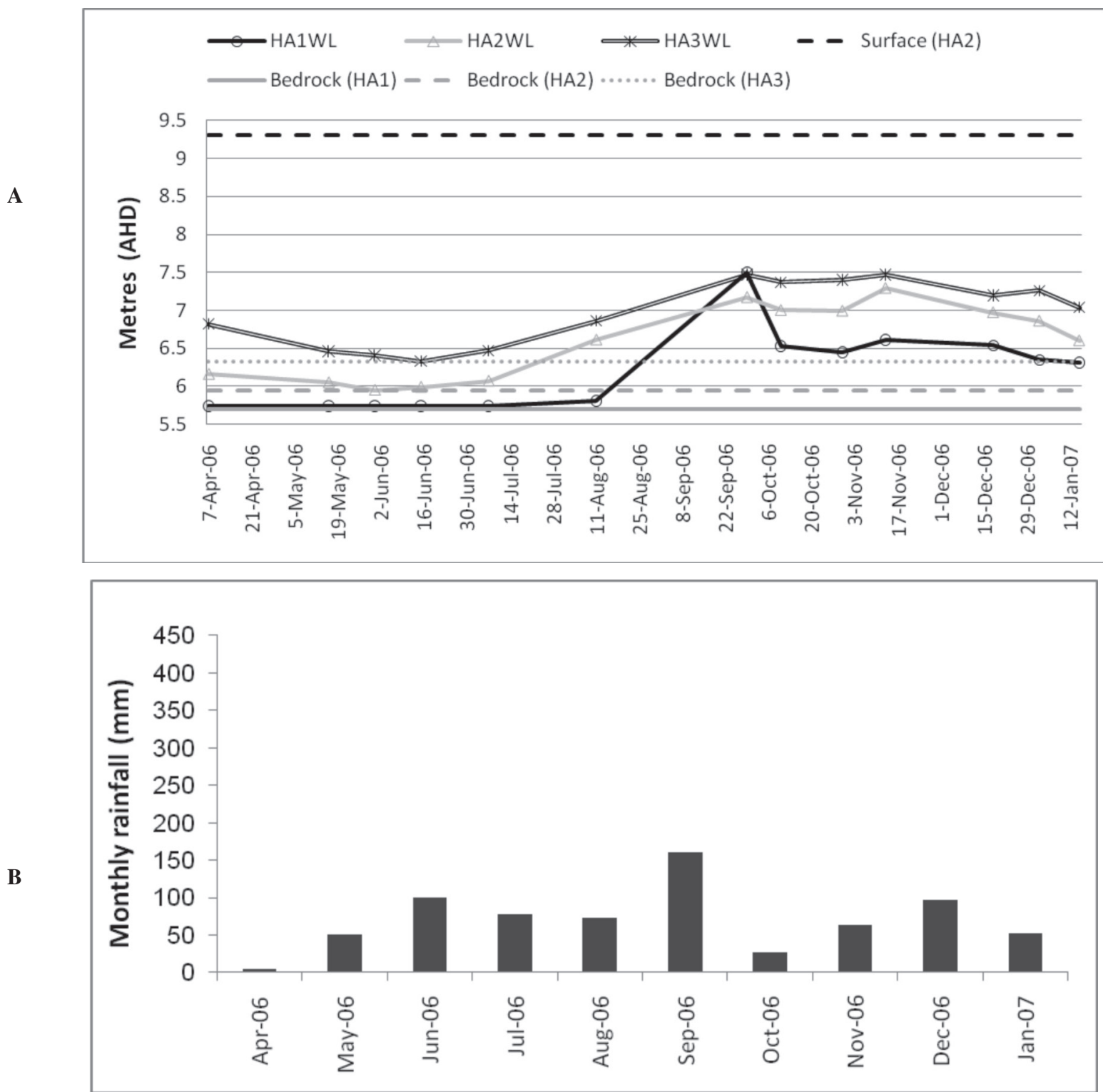

Fig. 9. Measured variables during construction (a) water table level and bedrock elevations for each piezometer (HA1, HA2 \& HA3) and ground surface at HA2; (b) monthly rainfall (Wyong Golf Club). See Figure 4 for the location of the three piezometers within the study area. 
Table 5: Water table levels beneath the Eucalyptus parramattensis regrowth forest prior to, during and after construction. Monthly rainfall data at the closest rainfall station (Wyong Golf Club). n/a - not applicable.

\begin{tabular}{|c|c|c|c|c|c|}
\hline & & HA1 & $\begin{array}{l}\text { table }(\mathrm{m}) \\
\text { HA2 }\end{array}$ & HA3 & $\begin{array}{l}\text { Rainfall } \\
(\mathbf{m m})\end{array}$ \\
\hline $\begin{array}{l}\text { Pre-construction } \\
(n=74)\end{array}$ & $\begin{array}{l}\text { Mean ( } \pm \text { SE) } \\
\text { Median } \\
\text { Minimum } \\
\text { Maximum } \\
\text { Amplitude }\end{array}$ & $\begin{array}{l}6.5 \pm 0.06 \\
6.5 \\
5.7 \\
7.5 \\
1.7\end{array}$ & $\begin{array}{l}7.1 \pm 0.05 \\
7.1 \\
6.2 \\
8.0 \\
1.8\end{array}$ & $\begin{array}{l}7.4 \pm 0.05 \\
7.5 \\
6.6 \\
8.2 \\
1.6\end{array}$ & $\begin{array}{l}75 \pm 10.8 \\
61 \\
0 \\
325 \\
\text { n/a }\end{array}$ \\
\hline $\begin{array}{l}\text { During construction } \\
(n=13)\end{array}$ & $\begin{array}{l}\text { Mean ( } \pm \text { SE) } \\
\text { Median } \\
\text { Minimum } \\
\text { Maximum } \\
\text { Amplitude }\end{array}$ & $\begin{array}{l}6.2 \pm 0.14 \\
6.3 \\
5.7 \\
7.5 \\
1.8\end{array}$ & $\begin{array}{l}6.6 \pm 0.12 \\
6.6 \\
6.0 \\
7.3 \\
1.3\end{array}$ & $\begin{array}{l}7.0 \pm 0.11 \\
7.0 \\
6.3 \\
7.5 \\
1.1\end{array}$ & $\begin{array}{l}71 \pm 13.5 \\
68 \\
5 \\
160 \\
\text { n/a }\end{array}$ \\
\hline $\begin{array}{l}\text { Post-construction } \\
(n=11)\end{array}$ & $\begin{array}{l}\text { Mean ( } \pm \text { SE) } \\
\text { Median } \\
\text { Minimum } \\
\text { Maximum } \\
\text { Amplitude }\end{array}$ & $\begin{array}{l}6.9 \pm 0.15 \\
7.1 \\
6.2 \\
7.4 \\
1.2\end{array}$ & $\begin{array}{l}7.1 \pm 0.13 \\
6.9 \\
6.5 \\
7.7 \\
1.2\end{array}$ & $\begin{array}{l}7.3 \pm 0.12 \\
7.2 \\
6.9 \\
7.9 \\
1.0\end{array}$ & $\begin{array}{l}134 \pm 26.6 \\
115 \\
19 \\
397 \\
\text { n/a }\end{array}$ \\
\hline
\end{tabular}

Table 6. Mean ( \pm s.e.) percentage foliage loss of Eucalyptus parramattensis trees at the Warnervale study site at the start and end of the study period.

\begin{tabular}{lcc} 
& \multicolumn{2}{c}{ Mean Percentage Foliage Loss } \\
& September $\mathbf{2 0 0 3}$ & July 2011 \\
Eastern (regrowth) & $32.5 \pm 8.1(10$ trees $)$ & $35.4 \pm 7.0(11$ trees $)$ \\
Western (mature) & $51.8 \pm 8.0(9$ trees $)$ & $30.6 \pm 7.6(11$ trees $)$
\end{tabular}

Table 7. Groundwater salinity levels (ppt) recorded beneath the regrowth (eastern) and mature (western) Eucalyptus parramattensis Woodland (in 2009 during the post-construction period ) $(n=8)$. Means with different subscripts indicate that differences are significant at the $p<0.05$ level.

Date

16.10 .09
26.10 .09
2.11 .09
29.12 .09
14.01 .10
09.02 .10
29.07 .10
08.10 .10
Mean \pm SE

Regrowth Eucalyptus parramattensis Woodland

\begin{tabular}{c} 
HA1 \\
8.5 \\
8.2 \\
7.9 \\
8.6 \\
7.9 \\
8.0 \\
9.6 \\
9.3 \\
$8.5 \pm 0.23$ \\
\hline
\end{tabular}

HA2
11.3
11.2
10.9
12.4
11.4
11.4
11.6
11.3
$11.4 \pm 0.16_{b}$

Mature Eucalyptus
parramattensis Woodland
HA5
17.9
0.4
2.6
13.4
9.9
0.7
1.3
1.2
$5.9 \pm 2.42 \mathrm{abcd}$

Old farm dam

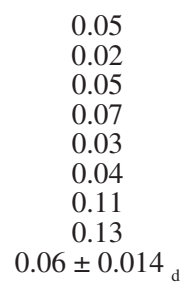

\section{Soil Moisture and Temperature}

Higher mean soil moisture tensions were observed within the Western-mature forest (HA4-HA6) and at HA1 (Table 4). On average, soil moisture tension was lowest at two of the stations (HA2 and HA3) within the Eastern-regrowth forest. Mean soil temperature was significantly lower within the western mature forest than the eastern regrowth forest $(\mathrm{t}=$ -16.8 ; d.f. $=4$; $\mathrm{p}<0.001$ ) (Table 4).

Wetting and drying cycles within the topsoil showed the greatest fluctuations in soil moisture (Stations HA4 to HA6) were in the Western-mature forest where little ground cover vegetation exists (Figure 8b). In the Eastern-regrowth area, wide fluctuations in soil moisture tension were observed at HA1, similar to that within the mature forest, but in contrast to the relatively stable soil moisture tensions recorded at HA2 and HA3 (Figure 8a). The soil profiles indicated that the topsoil at HA1 was clay and similar to that at HA4, HA5 and HA6, whilst the topsoil at HA2 and HA3 was silty sand (Figure 6). HA1, HA4, HA5 and HA6 probably had soil moisture tensions that are variable because the clay topsoils would hold water more tightly when conditions are dry and water would be slow to infiltrate when conditions are wet. In contrast, HA2 and HA3 probably had more stable soil moisture tensions because the sandy topsoils allows water to infiltrate and drain away relatively quickly. 
A
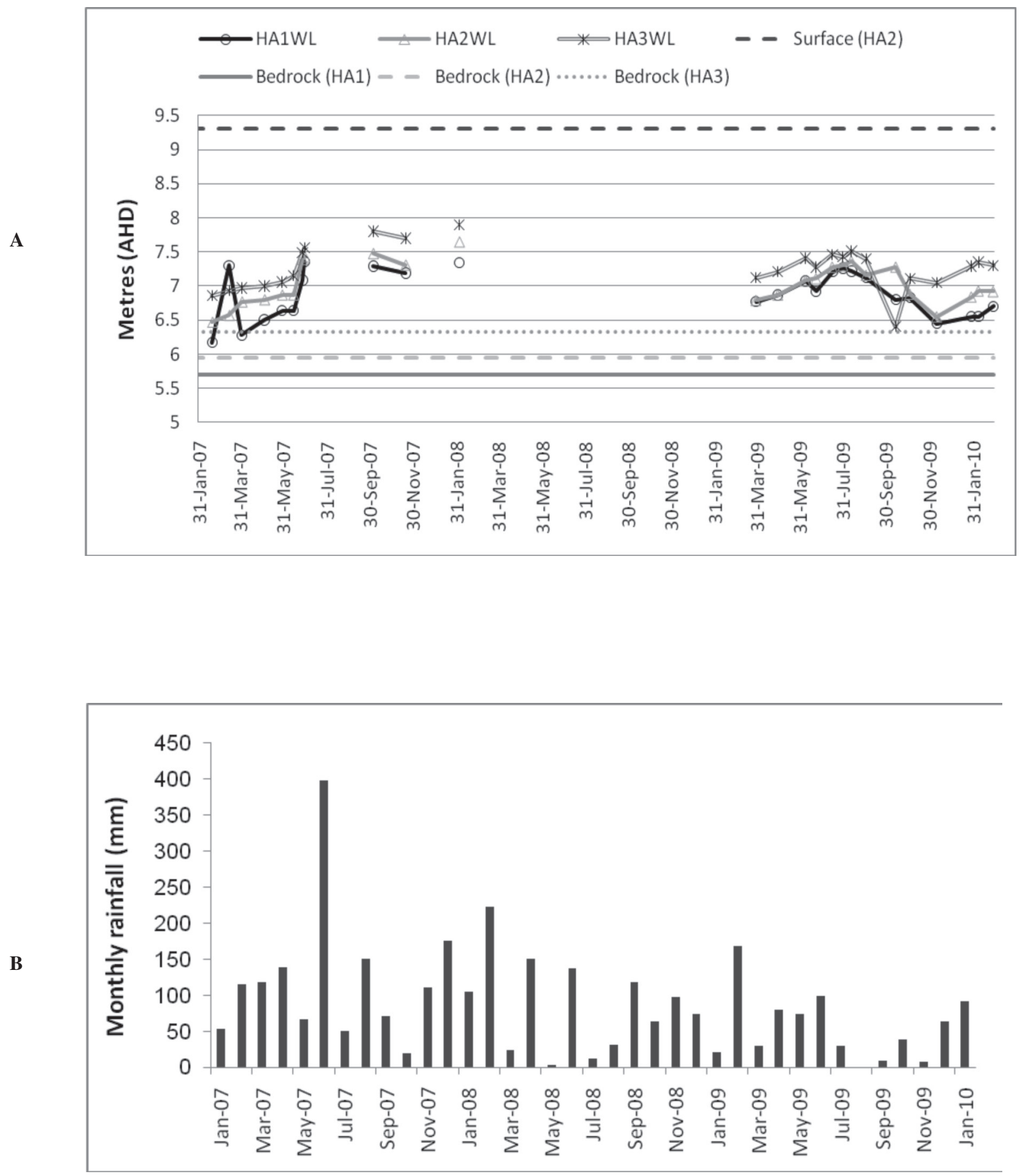

Fig. 10. Measured variables after construction (a) water table level and bedrock elevations for each piezometer (HA1, HA2 \& HA3) and ground surface at HA2; (b) monthly rainfall (Wyong Golf Club). See Figure 4 for the location of the three piezometers within the study area. Note there is a gap in data recording for the post-construction period. 
Significant negative correlations between soil moisture tension and rainfall occurred at HA1 $(\mathrm{r}=-0.38, \mathrm{p}<0.05, \mathrm{n}$ $=61)$, HA4 $(\mathrm{r}=-0.35, \mathrm{p}<0.05, \mathrm{n}=61)$ and HA5 $(\mathrm{r}=-0.40$, $\mathrm{p}<0.05, \mathrm{n}=61)$. Soil moisture tension and water table level were significantly negatively correlated at the three stations where water tables were monitored $(\mathrm{HA} 1, \mathrm{r}=-0.30, \mathrm{p}<0.05$, $\mathrm{n}=67 ; \mathrm{HA} 2, \mathrm{r}=-0.37, \mathrm{p}<0.01, \mathrm{n}=67 ; \mathrm{HA} 3, \mathrm{r}=-0.38, \mathrm{p}<$ $0.01, n=67)$.

\section{Results-During and after construction}

\section{Water table levels}

During the construction period the water table levels at the three stations in the Eastern-regrowth area were, on average, 0.3-0.5 m lower, and much more variable, than during the pre-construction period (Table 5). Post-construction water table levels, at HA2 and HA3, were similar to preconstruction levels. Repeated measures ANOVA showed that water table levels between the treatments (i.e. pre-, during and post-construction) were significantly different $(2 \mathrm{df} ; \mathrm{F}=$ $5.7 ; \mathrm{p}<0.01)$.

Post hoc Bonferroni tests showed that there was a significant difference between water tables, prior to and during construction ( $2 \mathrm{df} ; \mathrm{p}<0.01)$, as well as between water tables during and post-construction $(2 \mathrm{df} ; \mathrm{p}<0.05)$. However, pre- and post-construction water tables were not significantly different ( $2 \mathrm{df} ; \mathrm{p}>0.05$ ). The amplitude of the water table was greatest during the pre-construction period, most likely due to the variability in rainfall during this period (Table 5; Figure 9). Median monthly rainfall (Table 5) was significantly greater during the post-construction period than during pre-construction $\left(2 \mathrm{df} ; \chi^{2}=6.6, \mathrm{p}<0.05\right)$.

Repeated measures ANOVA demonstrated that there was a significant difference in water table levels between the piezometer locations ( $2 \mathrm{df} ; \mathrm{F}=634.0 ; \mathrm{p}<0.001$ ), as well as a significant interaction between piezometer location and treatment ( $4 \mathrm{df} ; \mathrm{F}=22.2 ; \mathrm{p}<0.001)$. That is, the effect of construction on the water table was dependent on the location of the piezometer. The nature of this interaction can be seen in the water table response to the $160 \mathrm{~mm}$ rainfall event in September 2006; where the rise and fall of the water table at HA1, was much greater than at stations HA2 and HA3 (Figure 9). During large rainfall events, the north-eastern facing slope without any vegetation cover caused more runoff to flow to the base of the slope, and the ponding of surface water at HA1 (i.e. the piezometer station closest to the base of the slope) resulted in the water table rising above the levels of HA2 and HA3. Such events altered the normal (i.e. dipping to the south-west) water table gradient beneath the Eucalyptus parramattensis Woodland (Figure 9). This trend during high rainfall events continued after construction (e.g. March 2007), but only while the grass cover on the slope was being established (Figure 10). Following the establishment of the grass cover, the water table gradient re-stabilised to pre-construction levels (Figure 10; Table 5).

\section{Tree condition}

In 2003, the mean percentage foliage loss indicated that the trees in the Western-mature area were in a poorer condition than those in the Eastern-regrowth area (Table 6). In May 2009 those trees that could be found with their original tags were reprouting via epicormic shoots; one of the tagged trees in the western area had died. By July 2011 the condition of the trees in the Western-mature area (in terms of foliage loss) had improved; the condition of the trees in the Easternregrowth area remained the same. However, ANOVA showed that there was no significant difference in mean percentage foliage loss between the eastern and the western areas ( $1 \mathrm{df}$; $\mathrm{F}=0.37 ; \mathrm{p}=0.65$ ), nor between the two time periods ( $1 \mathrm{df}$; $\mathrm{F}=0.58 ; \mathrm{p}=0.58)$ and there was no interaction between time and location.

\section{Groundwater Salinity}

Groundwater salinity was only measured in 2009 (postconstruction), and was consistently 8-12 ppt in the Easternregrowth area, ranged from $0.6-18 \mathrm{ppt}$ in the Western-mature area, and was insignificant in the water in the adjacent farm dam (see Figure 1 for location) (Table 7). Repeated measures ANOVA demonstrated that there was a significant difference (4 df; $F=21.0 ; p<0.01)$ in groundwater salinity among the five locations examined (Table 7) but Post hoc Bonferroni tests showed that the only significant differences in salinity between locations were those involving comparisons with HA5 (Table 7). This was due to the extreme variability in salinity recorded at HA5, suggesting that the seal between the PVC pipe and the surrounding soil was poor and surface water was entering the piezometer.

Mean ( \pm SE) water table levels (AHD reduced levels) during the period of salinity measurements were $6.8 \pm 0.40 \mathrm{~m}$ at $\mathrm{HA} 1,7.0 \pm 0.41 \mathrm{~m}$ at HA2, $7.3 \pm 0.41$ at HA3 and $6.8 \pm 0.88$ $m$ at HA5. The higher variability in water table levels at HA5 is also consistent with surface water entering the piezometer. As most of the readings in Table 7 were taken after rain, the low salinity levels sometimes recorded at HA5 may be explained by the fresh surface water inputs sitting on top of the more saline groundwater. An additional sample taken during drier conditions (February 2011) recorded salinity levels at HA1 and HA2 of a similar order to those shown in Table 7, whilst salinity recorded at HA3 and HA5 were 3.1 ppt and $2.1 \mathrm{ppt}$, respectively. 


\section{Discussion}

\section{Vegetation, soils and water table depth}

At Warnervale Eucalyptus parramattensis trees occur at sites associated with clay soils derived from Patonga Claystone where there is a high water table, within $1.4 \mathrm{~m}$ of the surface, but where the water table can drop to as deep as $3.1 \mathrm{~m}$ during droughts (i.e. pre-construction levels at HA2). It has been shown throughout this study that water levels in the Porters Creek aquifer increase after rainfall events (with a lag period) and decrease when rainfall is low. These results are consistent with those gathered from the Swan Coastal Plain in Western Australia where water levels consistently increase after recharge from winter rainfall (with a lag period) and decrease during the dry summer period (e.g. Groom et al. 2000). At the Porters Creek aquifer the level of drawdown is substantial, with groundwater levels at HA1 being at bedrock level ( $4.5 \mathrm{~m}$ below the surface) between May \& September 2004, when groundwater levels at HA2 \& HA3 were also low ( $2.9 \mathrm{~m}$ and $2.7 \mathrm{~m}$ respectively below the surface) (see Fig. 7).

Analyses of historical rainfall data for the NSW Central Coast (Erskine \& Townley-Jones 2009) show significant multi-decadal periods of high rainfall (1863-1900, 19491990) alternating with low rainfall (1901-1948, 1991-2008). Although the underlying meterological causes are unclear, El Niño-Southern Oscillation events and/or Interdecadal Pacific Oscillation (IPO) phases are possibly involved (Erskine \& Townley-Jones 2009). Analysis of rainfall data from Wyong Golf Club shows that the low annual rainfall experienced during 1991-2008 was not significantly different to that experienced during 1901-1984. That is, mean annual rainfall at Wyong during these two drier periods was similar and was $200-300 \mathrm{~mm}$ lower than during the high rainfall periods of 1885-1900 and 1949-1990 (Erskine \& TownleyJones 2009). Thus, any long-lived phreatophytic plants at our study site have experienced episodes of limited access to groundwater similar to that found in the current study and would have some capacity to survive these periods (e.g. by using available soil moisture or tolerating water stress). It is possible that the population of Eucalyptus parramattensis has survived previous episodes of canopy dieback; it was obvious from the regular visits that the ground understorey vegetation was only present during wetter periods.

The subcanopy of the Western-mature Eucalyptus parramattensis Woodland which was located in the lowest areas (i.e. 8-9 m AHD) with clay topsoils, is dominated by Melaleuca nodosa, while Melaleuca sieberi dominated the slightly higher elevation of the Eastern regrowth forest (i.e. 9.3-9.4 m AHD) where the topsoil was sandier. The association of Melaleuca nodosa with a shallow water table is consistent with Griffith et al. (2004) who showed that the roots of Melaleuca nodosa seedlings planted in dry heath had reached the water table (1-1.5 m below the surface) after 6 months of growth. There appears to be no information on the root depth of Eucalyptus parramattensis. However a NSW north coast study shows the roots of heathland plants $(0.25-1 \mathrm{~m}$ high) can access water table depths greater than $7 \mathrm{~m}$ (Griffith et al. 2008); in south-western Western Australia the roots of Banksia ilicifola can reach depths of $9 \mathrm{~m}$ (Groom 2004). These findings suggest that the aquifer identified in this study is likely to be within the reach of Eucalyptus parramattensis roots, and other shrubs at the site (e.g. Melaleuca nodosa). Thus, according to the guidelines of Eamus et al. (2006b) the Eucalyptus parramattensis woodland at the study site is an example of a groundwaterdependent ecosystem because of the subsurface presence of groundwater and the likelihood that the roots of the canopy plant species can access the water table and capillary fringe.

Groundwater-dependent vegetation is susceptible to the rate and season of drawdown (Eamus \& Froend 2006). During a relatively dry period the Eucalyptus parramattensis population in this study experienced water table drawdown rates of $0.27 \mathrm{~m}$ per month, a rapid drawdown rate compared, for example, to that observed during the same period by Chalmers et al. (2009) in a shallow ( $2 \mathrm{~m}$ deep) alluvial aquifer immediately adjacent to Widden Brook (Upper Hunter, NSW). Substantial rainfall (> $600 \mathrm{~mm}$ over a four month period) was shown to replenish the water table in the current study by about $1 \mathrm{~m}$. Recharge of the groundwater after large rainfall events (> $250 \mathrm{~mm}$ in a month) could take up to a month when prior conditions had been relatively dry.

The canopy dieback evident in Eucalyptus parramattensis individuals at the start of the study in 2003 may be due to a number of causes. Some eucalypts survive drought by stomatal control (i.e. reducing transpiration), while others grow extensive and deep root systems to reach water unavailable to other plants (Bell \& Williams 1997). Some drought-tolerant eucalypts have been shown to accumulate high concentrations of solutes in tissues (osmotic adjustment) to maintain turgor, or have vessel elements (narrow and thick-walled) that allow them to tolerate low water potentials without cavitation (Bell \& Williams 1997). Additional strategies phreatophytic species may use to avoid water deficits include the ability for root growth to keep pace within declining water tables (Gurnell et al. 2001), root patterns that enable the use of more than one type of water resource (Mensforth \& Walker 1996; O'Grady et al. 2002; Groom 2004) and the redistribution of groundwater or deep soil moisture by hydraulic lift (Groom 2004). Thus, the failure of any of these mechanisms may be responsible for the canopy dieback in Eucalyptus parramattensis and further work would be required to determine the primary 
cause(s). By the end of the study some of the Eucalyptus parramattensis individuals showed signs of recovery, producing epicormic shoots to replace foliage lost before the study commenced. Although it is likely that this recovery is linked to the rise in the maximum depth of the water table at the end of the drought, it should be noted that the water table level when foliage was lost is unknown and the trees may also be responding to increased soil water availability from higher rainfall during the post-construction period.

The lack of any significant differences in the mean percentage foliage loss of the Eucalyptus parramattensis individuals sampled at the start and the end of the study may be a consequence of the small sample size, the loss of tags and that the foliage loss classes used were too broad to be useful. The methods of Stone and Haywood (2006), which also involves estimating the proportion of the current tree crown which is of epicormic origin, should be considered for future studies. Other improvements would be to examine long-term plant response to water stress by measuring population vigour, and short-term responses by measuring leaf water potential or stomatal conductance (Eamus et al. 2006). Further, the current study could not determine the extent to which Eucalyptus parramattensis is dependent on groundwater or how this use changes as groundwater availability varies. Studies similar to O'Grady et al. (2001) and Groom (2004), where sources and patterns of water use are determined by measuring stable isotopes of hydrogen $\left({ }^{2} \mathrm{H}\right)$ or oxygen $\left({ }^{18} \mathrm{O}\right)$ and leaf or shoot water-potentials are needed.

\section{Groundwater salinity}

According to Lothian and Williams (1988) the boundary between 'fresh' and 'saline' water is imprecise and definitions vary according to need (e.g. an ecologist's definition will differ from a manager of water for human consumption). Ecologists working on inland wetlands in South Australia define fresh as $<3 \mathrm{ppt}$, slightly saline as $3-10 \mathrm{ppt}$, saline as $10-100 \mathrm{ppt}$ and highly saline as $>100 \mathrm{ppt}$ (Lothian \& Williams 1988). Based on this definition, the groundwater beneath the Eucalyptus parramattensis Woodland ranged from slightly-saline to saline. The aquifer associated with Patonga Claystone becomes unconfined north-east of the Wyong River and, consistent with our results, is "generally considered to be low yielding, with moderate to high salinity levels" (Molloy et al. 2009, p. 8). This contrasts with the fresh groundwater $(<0.35 \mathrm{ppt})$ recorded beneath a floodplain supporting Casuarina cunninghamiana forest adjacent to Widden Brook (Chalmers et al. 2012), and in a coastal aquifer below Wallum communities of northern NSW (Griffith et al. 2008). The order of magnitude difference in groundwater salinity levels between the current study and that of Griffith et al. suggests that species that the two studies have in common (e.g. Melaleuca nodosa and Melaleuca sieberi) have a wide tolerance of groundwater salinity.
In this study salinity was only measured during a relatively wet period, and as we could expect groundwater salinity to have been higher (i.e. saline) during the past drought, there must have been long periods during drought when saline water was the main source of moisture. Some freshwater plants can tolerate salinities as high as $20 \mathrm{ppt}$ (Lothian \& Williams 1988) but in areas such as the Chowilla floodplain in South Australia, where riparian communities (particularly Eucalyptus camaldulensis) are suffering severe declines in health, the salinity of the shallow $(<5 \mathrm{~m})$ groundwater typically ranges from $22-54$ ppt (Overton et al. 2006). The relative contribution of water stress or salinity to the poor tree health of Eucalyptus parramattensi observed in the current study cannot be determined from our data.

The salinity and declining tree health on the Chowilla floodplain is driven by a lack of flooding and rising saline groundwater tables resulting from river regulation (Overton et al. 2006). Eucalyptus largiflorens Black Box has been shown to be reliant on moderately saline $(<26 \mathrm{ppt}$ ) groundwater, but where salinity exceeds $26 \mathrm{ppt}$ on the floodplains of the River Murray it opportunistically uses low-salinity deep soil water, together with other water sources such as rainfall (Holland et al. 2006). The low-salinity deep soil water is recharged vertically by rainfall (and floodwaters) or horizontally by bank recharge from the River Murray or ephemeral creeks (Holland et al. 2006). Infiltration of floodwaters and rainfall to the water table occurs through preferential flow paths in clayey soils (e.g. tree-root channels, cracks in clay \& topographic depressions) and by diffuse flow in sandy soils where the clay is absent at the break of slope (Holland et al. 2006). Recharge through infiltration of rainfall and water flowing through the narrow drainage depression may be important in lowering the salinity of soil water and groundwater underlying the Eucalyptus parramattensis Woodland. Considering that the topsoil at HA1 was clayey and that of HA2 and HA3 was sandier, the lower average salinity at HA1 suggests some kind of preferential flow path within the vicinity of this piezometer (which was located at the break of the slope). Nevertheless, areas with sandy soils (such as those in the vicinity of HA2 and HA3) would be expected to be important for infiltration of rainfall into the water table.

\section{Vegetation and soil moisture}

The significant correlation between water table depth and soil moisture suggests that at times the capillary fringe above the water table extends to $30 \mathrm{~cm}$ below the ground surface. The relationship between soil moisture tension and water table level is consistent with Groom et al. (2000a), who found that on the deep sands of the Swan Coastal Plain "groundwater levels are closely tied to rainfall events, which in turn, are directly related to soil moisture levels" (p. 81). Significant correlations between rainfall and soil moisture at HA1, HA4 and HA5, where the topsoils are clays were 
observed. Soil water availability was, on average, higher but more variable where the soils were clay; the locations of which correspond with the semi-cleared upslope position of HA1 and the stations within the mature woodland (HA4, HA5 and HA6). In contrast, the soil moisture availability in the eastern portion of the regrowth area (HA2 and HA3) was, on average, lower but less variable, due to the sandier topsoils.

Opportunistic water-use strategies have been demonstrated for a number of Australian tree and shrub genera (i.e. Eucalyptus, Melaleuca, Acacia, Banksia - Overton et al. 2006) growing in environments that experience periodic water deficits. The ability of Melaleuca halmaturorum to rapidly re-activate dormant roots at the depth where water is available is proposed as a mechanism to allow opportunistic use of different water sources (Mensforth \& Walker 1996) and it is likely that Eucalyptus parramattensis would also opportunistically use whatever source of water was available. The use of stable isotopes of water and water-potential techniques is needed to confirm this.

The density of Eucalyptus parramattensis trees was lower, and a number of individuals had died in the Eastern-regrowth area, where the topsoil is sandier and soil moisture generally lower. Where the topsoil is sandier the trees may rely on the water table to a greater degree and therefore may be more susceptible to water table declines during drought. However, clearing and grazing previously occurred in the eastern area confounding our results and we cannot determine if the latter habitat is more marginal for the species or not.

\section{Effect of construction on the water table}

The water table gradient found beneath the Eucalyptus parramattensis Woodland had an inverse relationship to the surface level. During and after disturbance on the adjacent slope (stage 2 construction), one piezometer (HA1) showed peak water table levels after large rainfall events over and above the levels further down slope (i.e. HA2 and HA3). This caused the water table gradient to alter, although no corresponding impact on the health of Eucalyptus parramattensis trees was detected. The reversal of the water table gradient can be explained by the clearing of slope vegetation and the increased runoff accumulating at the base of the slope. This effect continued whilst the slope was being revegetated, but once the grass cover was well established the water table gradient re-stabilised back to pre-construction levels. Pre- and post-construction mean water table depths were not significantly different from each other, but the fact that median monthly rainfall was significantly greater during the post-construction compared to pre-construction period confounds the results. For this reason, the study would have benefited from having a control site where water tables could be monitored in the absence of upslope clearing. Unfortunately in the case of this endangered population, finding a comparable control site was not possible.
Our findings are consistent with those observed by Jutras et al. (2006) in a study of water table changes following precommercial thinning of forested wetlands in Quebec in that the water table was affected in the first year, but hydrologic recovery occurred in the second year. Jutras et al. (2006) found that faster recovery on particular sites was related to an increase in ground cover which, with its higher interception rate, caused the water table depth to reach pre-treatment levels. However their findings differed from ours in that the mean water table levels rose (by $2 \mathrm{~cm}$ ) after tree removal, rather than declined. This discrepancy can be explained by the differences between the two studies. Their study involved canopy tree removal from a forested wetland, which reduced evapo-transpiration and caused a corresponding rise in the water table; the degree of the water table rise was related to the amount of basal area removed (Jutras et al. 2006). Our study involved not only the removal of canopy trees but an increase in impervious surfaces on a slope, above a wetland. Thus, any reduction in evapo-transpiration on the slope will not increase the water table if this is counteracted by impervious surfaces directing at least some of the increased runoff away from the wetland area via stormwater drains.

\section{Implications for management}

The findings of this study are applicable to other areas where groundwater-dependant Endangered Ecological Communities and Populations occur adjacent to upslope development. To minimize alteration of the water table, adjoining slopes need to be revegetated as quickly as possible after clearing, or clearing should be undertaken in stages. No impact on the health of the Eucalyptus parramattensis trees was observed to result from the short-term change to the water table. Whilst this finding is consistent with Griffith et al. (2008), who found that dry heath species could tolerate waterlogging for up to 3 months, the period of possible waterlogging in the current study was very brief (HA1 > HA2 for less than a month in Fig. 9). It should be noted that consistent waterlogging resulting from runoff directly flowing from adjacent impervious surfaces (e.g. isolated individuals retained in a carpark) can cause severe dieback in this tree species. While Eucalyptus parramattensis trees have a high requirement for soil moisture and may rely on shallow aquifers, like most woody species they cannot tolerate prolonged waterlogging and its tolerance of waterlogging may be less than that found in Swamp Sclerophyll Forest vegetation communities (Payne pers. obs.).

Given that the current study confirmed that a shallow aquifer is present below Eucalyptus parramattensis Woodland and the study area is at the upstream end of the catchment, it is likely that the aquifer is fed by the surrounding slopes to the north-east. Thus, management of runoff within the catchment is essential. Rather than allow surface runoff from the slopes to be diverted away from the aquifer underlying the Eucalyptus parramattensis Woodland (through road and stormwater drains associated with the development) 
a more conservative approach was adopted as part of this development. Pervious detention basins were constructed which captured the overland runoff (and fines of the Patonga Claystone soils) and allowed water to infiltrate and replenish the aquifer. Due to the clayey nature of the soils, runoff collected in the basins infiltrates slowly into the aquifer. Such basins, though economical to construct, require a high level of maintenance and over three years they became very weedy, which has implications for infecting adjoining sensitive vegetation communities. After seven years, and with management, a more natural community has developed.

Where Patonga Claystone soils are present, impervious constructed wetlands, whose function is to capture overland runoff, and treat the water through both its longer storage time and the uptake of nutrients by wetland plants, do not always achieve the desired results. Patonga Claystone soils are highly prone to erosion because of their low shear strength and slaking prone behaviour (Nunt-jaruwong, 2006), leading to high levels of turbidity. Measurements taken during rainfall and settling events in an impervious basin near, and at, the study site showed turbidity levels beyond the scale of the measuring instrument (the shallow muddy water meant that a representative sample to determine total suspended solids (TSS) was not possible). There is now a requirement that total suspended solids levels be below $50 \mathrm{mg} / \mathrm{l}$, prior to discharge through adjoining wetland ecosystems (Wyong Shire Council, pers. com.). However for this soil type, settlement of the fines below $50 \mathrm{mg} / \mathrm{l}$ is never achieved naturally and flocculation methods using alum-based polymers may not achieve the required turbidity levels (even after several attempts), and can result in aluminium levels many times the Australian Standard within the discharge water from the basin. Where such circumstances occur, the potential impacts on aquatic fauna within wetland vegetation communities need to be considered.

Whilst the water table was observed to re-stablise to preconstruction levels in this study, broad-scale clearing and increases in impervious surfaces within the catchment may have a cumulative effect on the hydrologic regime. Although broadscale clearing of habitats may have an economic and social basis, the environmental cost needs to be acknowledged because many habitats bordering wetlands have Endangered Ecological Communities and Populations. The impact of urban development on coastal floodplain wetlands is complicated further if the groundwater upon which some species depend is saline (as in this study). Similar to floodplains in the drier parts of Australia, rainfall and floodwater infiltration may play a crucial role in maintaining groundwater salinities and soil water at levels that the existing vegetation can tolerate. Developments that impede this recharge may add to the multiple stresses (natural and human induced) already experienced by these vegetation communities. Long-term monitoring of the groundwater underlying coastal woody wetlands will be required if we are to adequately understand the impacts of urban development, drought and the possible risk posed by climate change on the health and recruitment of wetland Endangered Populations such as Eucalyptus parramattensis Woodland.

\section{Conclusion}

The Eucalyptus parramattensis Endangered Population at Warnervale occurs on a narrow drainage depression above a shallow slightly-saline to saline groundwater aquifer (8$12 \mathrm{ppt}$; $1.4-3.1 \mathrm{~m}$ deep). A water table gradient was found beneath the Eucalyptus parramattensis Woodland which had an inverse relationship to the surface level. Most Eucalyptus parramattensis trees occur where the water table is higher. A study using stable isotopes of water and water-potential techniques is needed to determine the extent to which Eucalyptus parramattensis uses groundwater and soil water sources.

Although in the initial stages of the study (2003) some Eucalyptus parramattensis trees died, no further impact on the trees was found and most trees are now in the state of recovery (2012). It is likely that the poor health of Eucalyptus parramattensis, which initiated this study, was due to water stress from a lowering water table (and/or an increase in groundwater/soil salinity) during drought. Trees at slightly higher elevations or on sandier soils may be expected to suffer greater stress.

Land-clearing for an upslope development significantly decreased the average water table level below the Eucalyptus parramattensis Woodland during the construction phase. Peaks also occurred at the base of the slope after large rainfall events, having the effect of reversing the direction of the water table gradient. However, the hydrology appeared to re-stabilise to pre-construction levels once the upslope area had been landscaped and revegetated with grass. Whilst this construction event did not show any impacts on the health of Eucalyptus parramattensis trees within the woodland, isolated trees retained within the development (and surrounded by impervious surfaces) suffered dieback illustrating that the species cannot tolerate continuous waterlogging.

Soil mapping is recommended around groundwaterdependant ecosystems likely to be impacted by development projects. Soil type determines where runoff water can be captured, held and allowed to infiltrate efficiently back into the aquifer, and consideration of soil maps prior to the construction of pervious detention basins will help ensure that maximum environmental benefits are achieved.

Further investigations of water table and groundwater salinity fluctuations in coastal wetlands is warranted, particularly in areas where climate change predictions suggest a risk of increased drought severity and/or rising groundwater associated with sea level rise. As climatic cycles occur on the scale of decades (Erskine \& Warner 1988), monitoring to determine the cumulative effects of land-clearing, and increased, within catchment, impervious 
surfaces on groundwater-dependant Endangered Ecological Communities and Populations will need to be long-term (especially where unimpacted control sites are unavailable).

\section{Acknowledgements}

The Lakes Grammar - an Anglican School provided funds for the aquifer investigation. We thank Jenny Evans, Howard Townsend and Tristan Stevenson whom guided the project over the many years. Coffey Geosciences installed the piezometers and provided the soil logs. Trehy, Ingold \& Neate and Clarke Dowdle \& Associates prepared all survey information. We also thank Sharyn Styman of Wyong Shire Council for providing data on floodplain mapping, Robyn Meldrum and Boris Branwhite who helped in the field, Wayne Erskine for helpful feedback on an early version of the manuscript and Michael Somerville for preparation of Figure 1. The constructive feedback provided by two reviewers is gratefully acknowledged.

\section{References}

Bell, D.T. \& Williams, J.E. (1997) Eucalypt physiology. In: Eucalypt Ecology: Individuals to Ecosystems (eds. J.E. Williams \& J. C. Z. Woinarski) pp. 168-196. Cambridge University Press, Melbourne.

Bell, S.J.B. (2002) The Natural Vegetation of the Wyong Local Government Area, Central Coast, NSW. Wyong Shire Council.

Benson, D. \& McDougall, L (1998) Ecology of Sydney plant species Part 6 Dicotyledon family Myrtaceae. Cunninghamia 5(4): 808-987.

Chalmers, A.C., Erskine W.D., Keene A. \& Bush R. (2009) Flow regimes influencing riparian vegetation on an unregulated sand-bed stream in the Hunter Valley, NSW. Proceedings of the $32^{\text {nd }}$ Hydrology and Water Resources Symposium). Newcastle, Engineers Australia, pp. 770-781.

Chalmers, A.C., Erskine W.D., Keene A. \& Bush R. (2012) Relationship between vegetation, hydrology and fluvial landforms on an unregulated sand-bed stream in the Hunter Valley, Australia. Austral Ecology 37(2), 193-203

Cooper, D.J., Sanderson, J.S. Stannard, D.I. \& Groenveld, D.P. (2006) Effects of long-term water table drawdown on evapotranspiration and vegetation in an arid region phreatophyte community. Journal of Hydrology 325, 21-34.

Eamus, D. \& Froend, R. (2006a) Groundwater-dependent ecosystems: the where, what and why of GDEs. Australian Journal of Botany 54, 91-6.

Eamus, D., Froend, R.,Loomes, R., Hose, G. \& Murray, B. (2006b) A functional methodology for determining the groundwater regime needed to maintain the health of groundwater-dependent vegetation. Australian Journal of Botany 54, 97-114.

Erskine, W.D. \& Townley-Jones, M. (2009) Historical rainfall changes on the Central Coast of NSW: Further Evidence of Alternating Rainfall Regimes. Proceedings of the $32^{\text {nd }}$ Hydrology and Water Resources Symposium, Newcastle, Engineers Australia, pp. 36-47.

Erskine, W.D. \& Warner, R.F. (1988) Geomorphic effects of alternating flood - and drought-dominated regimes on NSW coastal rivers. In: Fluvial Geomorphology of Australia (ed R.F. Warner) pp. 223-244. Academic Press, Sydney.
Griffith, S. J., Bale, C. \& Adam, P. (2004) The influence of fire and rainfall upon seedling recruitment in sand-mass (wallum) heathland of north-eastern New South Wales. Australian Journal of Botany 52, 93-118.

Griffith, S.J, Bale, B \& Adam, P. (2008) Environmental correlates of coastal heathland and allied vegetation. Australian Journal of Botany, 56, 512-526

Groom, P., Froend, R., Mattiske, E. \& Koch B. (2000a) Myrtaceous shrub species respond to long-term decreasing groundwater levels on the Gnangara Groundwater Mound, northern Swan Coastal Plain. Journal of the Royal Society of Western Australia $83,75-82$.

Groom, P., Froend, R. \& Mattiske, E. (2000b) Impacts of groundwater abstraction on a Banksia woodland, Swan Coastal Plain, Western Australia. Ecological Management \& Restoration 1 (2), 117-124.

Groom, P. K., Froend R. H., Mattiske E. M. \& Gurner R.P. (2001) Long-term changes in vigour and distribution of Banksia and Melaleuca overstorey species on the Swan Coastal Plain. Journal of the Royal Society of Western Australia 84, 63-9.

Groom, P.K. (2004) Rooting depth and water relations explains species distribution within a sandplain landscape. Functional Plant Biology 31; 423-428.

Harden, G.J. (Ed.) (1991) Flora of New South Wales. Volume 2. NSW University Press.

Hill S. J., Tung P. J. \& Leishman M. R. (2005) Relationships between anthropogenic disturbance, soil properties and plant invasion in endangered Cumberland Plain Woodland, Australia. Austral Ecology 30, 775-88.

Holland K.L., Tyerman S.D., Mensforth L.J. \& Walker G.R. (2006) Tree water resources over shallow, saline groundwater in the lower River Murray, south-eastern Australia: implications for groundwater recharge mechanisms. Australian Journal of Botany 54, 193-205.

Jutras S., Plamondon A. P., Hökkä H. \& Bégin J. (2006) Water table changes following precommercial thinning on post-harvest drained wetlands. Forest Ecology \& Management 235, 252-9.

Kooyman R. \& Rossetto M. (2006) Factors influencing species selection for littoral rainforest restoration: Do environmental gradients matter? Ecological Management \& Restoration 7, 113-22.

Lothian, J.A. \& Williams, W.D. (1988) Wetland conservation in South Australia. pp. 147-166. In: A.J. McComb \& P.S. Lake (eds.) The Conservation of Australian Wetlands. Surrey Beatty, Sydney.

Mackenzie B. D. E. \& Keith D. A. (2009) Adaptive management in practice: conservation of a threatened plant population. Ecological Management and Restoration 10, 129-35.

Mensforth L. J. \& Walker G. R. (1996) Root dynamics of Melaleuca halmatororum in response to fluctuating saline groundwater. Plant and Soil 184, 75-84.

Molloy, R., L. Lennon, et al. (2009). NSW Central Coast Opportunity Assessment for Aquifer Storage and Recovery. CSIRO Water for a Healthy Country Flagship Report to National Water Commission for Raising National Water Standards Project: Facilitating Recycling of Stormwater and Reclaimed Water via Aquifers in Australia - Milestone Report 3.3.1. http://www. clw.csiro.au/publications/waterforahealthycountry/2009/wfhcMAR-policy-design-milestone3.3.1.pdf (Accessed 19/4/2011)

Morris J.D. \& Collopy J.J. (1999) Water use and salt accumulation by Eucalyptus camaldulensis and Casuarina cunninghamiana on a site with shallow saline groundwater. Agricultural Water Management 39, 205-227. 
Nunt-jaruwong, S. (2006) Engineering geology of the Patonga Claystone, Central Coast, NSW with particular reference to slaking behaviour. School of Biological, Earth \& Environmental Sciences, UNSW PHD Thesis.

O’Grady, A.P., Eamus, D., Cook, P.G. \& Lamontagne, S. (2006) Groundwater use by riparian vegetation in the wet-dry tropics of northern Australia. Australian Journal of Botany 54, 145-54.

Overton I.C., Jolly I.D., Slavich P.G., Lewis M.M. \& Walker G.R. (2006) Modelling vegetation health from the interaction of the saline groundwater and flooding on the Chowilla floodplain, South Australia. Australian Journal of Botany 54, 207-220.

Payne, R. \& Duncan, S. (1999) The Natural Vegetation of the Wyong Local Government Area. Wyong Shire Council.

Reinelt L., Horner R. \& Azous A. (1998) Impacts of urbanization on palustrine (depressional freshwater) wetlands - research and management in the Puget Sound region. Urban Ecosystems 2, 219-36.

Scott M. L., Shafroth P. B. \& Auble G. T. (1999) Responses of riparian cottonwoods to alluvial water table declines. Environmental Management 23, 347-58.

Somerville, M. (2009) Hunter, Central \& Lower North Coast Vegetation Classification \& Mapping Project. Volume 1; Vegetation Classification Technical Report. HCC/REMS Hunter Councils Environment Division for Hunter-Central Rivers Catchment Management Authority, Tocal, NSW.

Stone, C. \& Haywood, A. (2006) Assessing canopy health of native eucalypt forests. Ecological Management \& Restoration 7, S24-S30.

Tabachnick B.G. \& Fidell L.S. (2006) Using Multivariate Statistics. Harper Collins, New York.

Uren R.E. (1975) The Geology and Low Cost Extractive Resources of the Gosford-Lake Macquarie Area: Volume 2. Geological Survey Report No: GS174/431. Geological Survey of New South Wales, Department of Mineral Resources, Sydney.

Manuscript accepted 2 April 2012

\section{Appendix 1}

\section{Vegetation descriptions of Eucalyptus parramattensis Woodland for a)Western and b)Eastern sites at Warnervale (recorded October 2003).}

a) Western - mature area

Open Woodland: Eucalyptus parramattensis subsp. parramattensis

Structure: Open woodland with a low closed forest beneath

Habitat: Alluvium overlying Patonga Claystone at depth on upper reaches of coastal freshwater swamps

Distribution: Porters Creek north of Wyong NSW

Floristic Composition: Isolated emergent trees of Eucalyptus parramattensis subsp. parramattensis project above the main canopy. A low closed forest forms the sub-canopy dominated by Melaleuca nodosa, Melaleuca sieberi and Melaleuca linariifolia. Understorey cover is generally sparse but in moister areas is dominated by Gahnia clarkei, Lepidosperma quadrangulatum and Carex appressa.

Related mapping units: Incorporated into MU26 Narrabeen Alluvial Drainage Line Complex of Bell (2004) and Eucalyptus parramattensis /Melaleuca sieberi/Swamp Mahogany swamp forest on the Central Coast of Somerville (2009)

b) Eastern - regrowth area

Open Woodland: Eucalyptus parramattensis subsp. parramattensis

Structure: Open woodland with a dense grassy understorey

Habitat: Alluvium overlying Patonga Claystone at depth on upper reaches of coastal freshwater swamps

Distribution: Porters Creek north of Wyong NSW

Floristic Composition: Isolated emergent trees of Eucalyptus longifolia occasionally occur. Either a low open regenerating woodland or a low forest is present dominated by Eucalyptus robusta, E. parramattensis subsp. parramattensis, E. amplifolia, Angophora floribunda, Melaleuca nodosa and $M$. sieberi are present. A further regenerating low open woodland layer of M. nodosa, E. parramattensis subsp parramattensis is often present.. The ground understorey grass cover is always dense and dominated by Andropogon virginicus, Briza minor, Briza maxima and Axonopus affinis.

Related mapping units: Incorporated into MU26 Narrabeen Alluvial Drainage Line Complex of Bell (2004) and Eucalyptus parramattensis IMelaleuca sieberi/Swamp Mahogany swamp forest on the Central Coast of Somerville (2009) 


\section{Appendix 2 a) Native plant species and b) Exotic species recorded from Eucalyptus parramattensis Wood- land at Warnervale (October 2003), 2 plots in western (mature) woodland and 1 plot in eastern (regrowth) woodland.}

a) Native species

Acacia longifolia subsp. longifolia Angophora floribunda

Carex appressa

Carex brunnea

Casuarina glauca

Cynodon dactylon

Cyperus difformis

Dianella caerulea var. producta

Dianella longifolia

Drosera auriculata

Entolasia stricta

Eragrostis sp.

Eucalyptus amplifolia

Eucalyptus longifolia

Eucalyptus parramattensis subsp. parramattensis

Eucalyptus robusta

Festuca spp.

Gahnia clarkei

Gonocarpus micranthus subsp.

micranthus

Gonocarpus tetragynus

Hydrocotyle peduncularis

Imperata cylindrica var. major

Juncus planifolius

Juncus usitatus

Lomandra longifolia

Melaleuca linariifolia

Melaleuca nodosa

Melaleuca sieberi

Microlaena stipoides

Microtis parviflora

Opercularia varia

Oxalis chnoodes

Oxalis sp.

Philydrum lanuginosum

Pratia purpurascens

Ranunculus inundatus

Ranunculus lappaceus

Schoenus sp.

Viola betonicifolia

Viola hederacea

Woollsia pungens
Family

Fabaceae

Myrtaceae

Cyperaceae

Cyperaceae

Casuarinaceae

Poaceae

Cyperaceae

Phormiaceae

Phormiaceae

Droseraceae

Poaceae

Poaceae

Myrtaceae

Myrtaceae

Myrtaceae

Myrtaceae

Poaceae

Cyperaceae

Haloragaceae

Haloragaceae

Apiaceae

Poaceae

Juncaceae

Juncaceae

Lomandraceae

Myrtaceae

Myrtaceae

Myrtaceae

Poaceae

Orchidaceae

Rubiaceae

Oxalidaceae

Oxalidaceae

Philydraceae

Lobeliaceae

Ranunculaceae

Ranunculaceae

Cyperaceae

Violaceae

Violaceae

Epacridaceae

\section{Frequency \\ 3 plots}

b) Exotic species

Andropogon virginicus

Asphodelus spp.

Axonopus fissifolius

Briza maxima

Briza minor

Cerastium glomeratum

Conyza sp.

Cyperus eragrostis

Hypochaeris radicata

Paspalum urvillei

Persicaria strigosa

Plantago lanceolata

Rubus fruticosus sp. agg.

Rumex crispus

Senecio madagascariensis

Stenotaphrum secundatum

Trifolium dubium

Vulpia bromoides
Family

Poaceae

Asphodelaceae

Poaceae

Poaceae

Poaceae

Caryophyllaceae

Asteraceae

Cyperaceae

Asteraceae

Poaceae

Polygonaceae

Plantaginaceae

Rosaceae

Polygonaceae

Asteraceae

Poaceae

Fabaceae

Poaceae

\section{Frequency \\ 3 plots}

1

3

2

3

2

3

2

3

2

2

2

1

1

3

2

2

2 